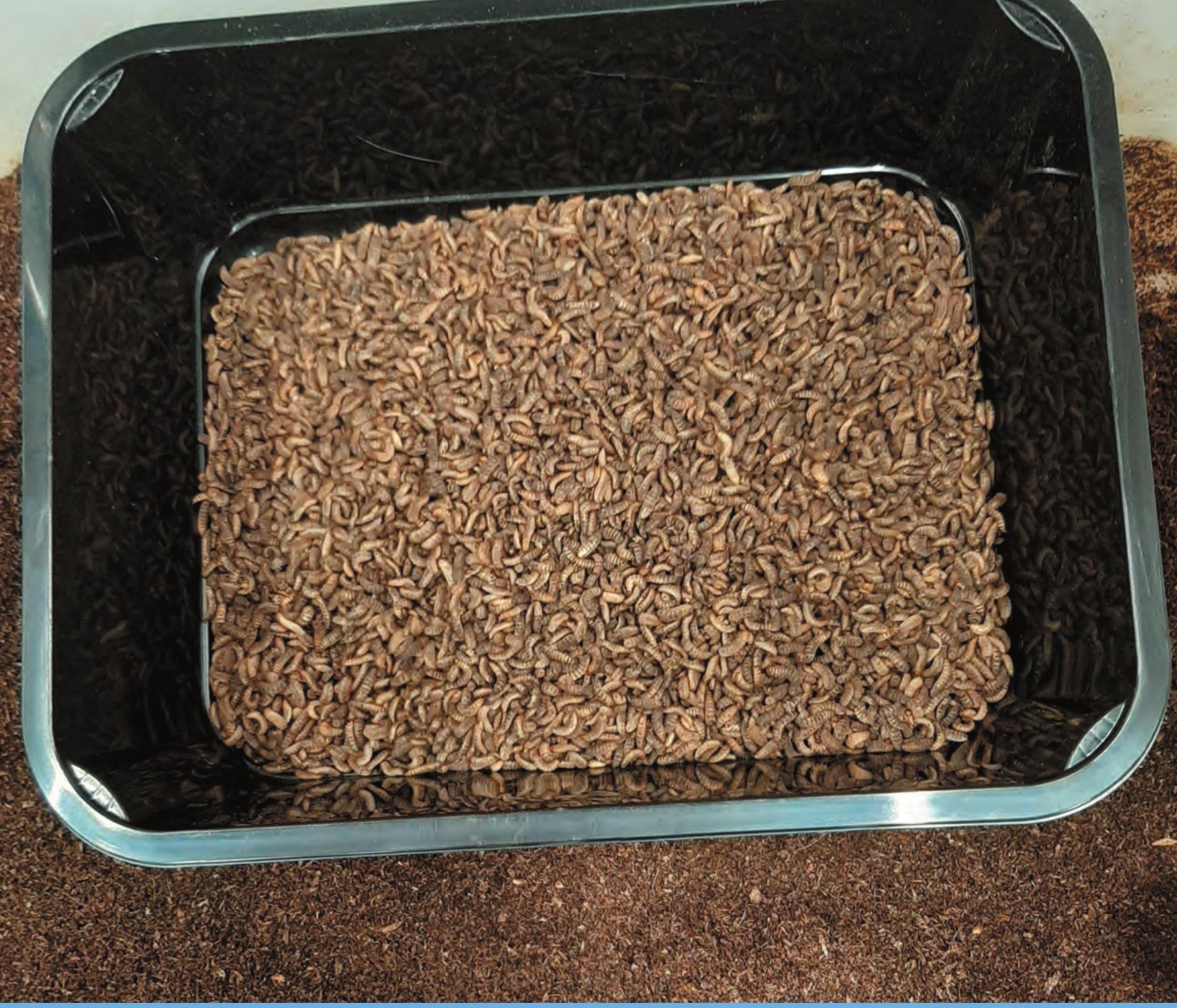

The profitability potential of black soldier fly (BSF) larvae raised on pig manure at farm level.

Authors: Ilse Groeneveld, Hellen Elissen, Klaas van Rozen and Rommie van der Weide

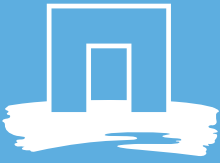
WAGENINGEN UNIVERSITY \& RESEARCH 


\section{The profitability potential of black soldier fly (BSF) larvae raised on pig manure at farm level}

Authors: Ilse Groeneveld, Hellen Elissen, Klaas van Rozen and Rommie van der Weide

This study was carried out by the Wageningen Research Foundation (WR), Business Unit Field Crops and was commissioned and financed by the PPP Biobased valorisation of manure and digestate AF-17052b. This project is financially supported by the Dutch Topsector Agri \& Food. Within the Topsector, private industry, knowledge institutes and the government are working together on innovations for safe and healthy food for 9 billion people in a resilient world. WR is part of Wageningen University \& Research, the collaboration of Wageningen University and Wageningen Research Foundation.

Wageningen, July 2021

WPR report 890 
Groeneveld, I., Elissen, H.J.H., van Rozen, K., van der Weide, R.Y., 2021. The profitability potential of black soldier fly (BSF) larvae raised on pig manure at farm level. Wageningen Research, Report WPR890. 40 pp.; 16 fig.; 40 tab.; 39 ref.

This report can be downloaded for free at: https://doi.org/10.18174/549892

Summary: As a growing demand for food and feed resources arises, alternative feed and food resources are sought to relieve pressures on the environment and existing food and feed resources. One alternative that has been given increasing interest is the application of black soldier fly (BSF) larvae to waste streams. In the context of the biobased economy, black soldier fly larvae convert waste streams into valuable insect biomass and organic fertilizer (frass). Applying black soldier fly larvae to manure has the potential to close loops within agri-food supply chains (Bortolini et al., 2020). This report explores the profitability potential of producing black soldier fly larvae on pig manure by individual pig farmers in the Netherlands. If profitable, producing black soldier fly larvae can diversify farmers' income streams and help farmers to increase the circularity and sustainability of their business. However, while steps have been taken to broaden EU legislation with regards to black soldier fly larvae, it is currently not yet legal to produce and sell black soldier fly larvae raised on manure.

Samenvatting: Door een toenemende vraag naar voedsel- en voederproducten, wordt er gezocht naar alternatieve methoden om voedsel- en voedingsproducten te creëren. Om het milieu en de huidige voedings- en voederbronnen minder onder druk te zetten. Eén van de alternatieven waar toenemende interesse in is, is de applicatie van black soldier fly (BSF) larven (ook wel zwarte soldatenvlieg genoemd) op reststromen. In de context van de biogebaseerde economie, BSF larven zetten reststromen om in waardevolle insectenbiomassa en organische meststof (frass). Het toepassen van BSF larven op mest heeft de potentie om kringen in de landbouwkringloop te sluiten (Bortolini et al., 2020). Dit rapport onderzoekt het winstpotentieel van BSF larvenproductie op varkensmest op individueel boerderijniveau in Nederland. Als dit blijkt winstgevend te zijn, kunnen BSF larven bijdragen aan het diversifiëren van inkomensstromen en bijdragen aan meer circulariteit en duurzaamheid van het boerenbedrijf. Tot nu toe zijn er stappen genomen om de EU wetgeving te versoepelen met betrekking tot BSF larven. Toch is het op dit moment nog niet wettelijk toegestaan om BSF larven gekweekt op dierlijke mest te produceren en verkopen.

Key words: black soldier fly larvae, pig manure, profitability, monte carlo analysis

(C) 2021 Wageningen, Stichting Wageningen Research, Wageningen Plant Research, Business Unit Field Crops, P. O. Box 430, 8200 AK Lelystad, The Netherlands; T +31 320291 111; www.wur.eu/ plantresearch

Chamber of Commerce no. 09098104 at Arnhem

VAT NL no. 8065.11.618.B01

Stichting Wageningen Research. All rights reserved. No part of this publication may be reproduced, stored in an automated database, or transmitted, in any form or by any means, whether electronically, mechanically, through photocopying, recording or otherwise, without the prior written consent of the Stichting Wageningen Research.

Stichting Wageningen Research is not liable for any adverse consequences resulting from the use of data from this publication.

WPR report 890

Photo Cover: Klaas van Rozen 


\section{Table of Contents}

Summary $\quad 4$

$\begin{array}{lr}\text { Samenvatting } & 6\end{array}$

$\begin{array}{llr}1 & \text { Introduction } & 7\end{array}$

2 Explanation of the calculation models $\quad 10$

2.1 Model A: A calculation tool for the profitability of black soldier flies on an individual farmer level.

2.2 Model B: A Monte Carlo inspired calculation tool for the profitability of black soldier flies for on individual farmer level.

3.1 Results Standard scenarios model A 13

3.1.1 Best Guess Scenario (A) 13

3.1.2 Best Guess Live Scenario (B) 15

$\begin{array}{ll}3.1 .3 \text { Medium Scenario (C) } & 17\end{array}$

3.1.4 Most favourable scenario (D) 18

$\begin{array}{ll}3.1 .5 \text { Least favourable scenario (E) } & 19\end{array}$

$\begin{array}{lll}3.2 & \text { Sensitivity analysis model A } & 20\end{array}$

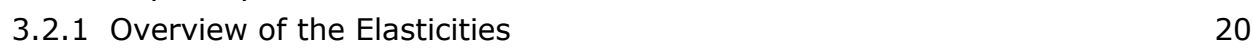

3.3 Results Standard scenarios model B $\quad 22$

3.3.1 High uncertainty scenarios I $\quad 22$

3.3.2 Medium uncertainty scenarios II $\quad 24$

$\begin{array}{ll}\text { 3.3.3 Low uncertainty scenario III } & 25\end{array}$

$\begin{array}{llr}5 & \text { Discussion } & 27\end{array}$

$\begin{array}{llr}6 & \text { References } & 29\end{array}$

Appendix 1 Overview of parameters in the dashboard of model A 31

Appendix 2 Definition of key financial numbers and metrics 32

Appendix 3 Input values for model A 33

Appendix 4 Additional tables and figures model A $\quad 34$

Best guess scenario $(A) \quad 34$

$\begin{array}{ll}\text { Best guess live scenario (B) } & 35\end{array}$

$\begin{array}{ll}\text { Medium scenario (C) } & 37\end{array}$

Most favourable scenario (D) $\quad 39$

$\begin{array}{ll}\text { Least favourable scenario (E) } & 40\end{array}$ 


\section{Summary}

As demand for food and feed resources grows due to a growing world population, alternative feed and food resources are sought to relieve pressures on the environment and existing food and feed resources (Smetana et al., 2019; Verbeke et al., 2015). One alternative that has been given increasing interest, is the application of black soldier fly (BSF) larvae to waste streams. In the context of the biobased economy, BSF larvae convert waste streams into valuable insect biomass and organic fertilizer (frass). In particular, applying BSF larvae to manure has the potential to close loops within agri-food supply chains and increase circularity (Bortolini et al., 2020). This report explores the profitability potential of producing BSF larvae on pig manure on a farm level in the Netherlands. An average Dutch pig farm has to process the pig manure of 1671 adult pigs (Wageningen University, 2020). This means that approximately $900,000 \mathrm{~kg}$ of wet pig manure has to be processed each year on the average Dutch pig farm. If one would process this with BSF larvae, this would result in approximately 89,000-104,000 kg of live BSF larvae per year, which could be turned into roughly 22,000-26,000 kg of dried insect biomass. The dried frass potential lies between $166,000-170,000 \mathrm{~kg}$ frass per year.

As for the profitability potential of BSF larvae raised on pig manure, a few parameters have a very large influence. The parameters influencing profit the most are the cost price of starter larvae $\left(P_{s l}\right)$, the sales price of dried/live larvae ( $\mathrm{P}_{\mathrm{BSF}}, \mathrm{P}_{\mathrm{BSF}}$ ), the margin of dried/live larvae ( $\left.\mathrm{M}_{\mathrm{BSF}}, \mathrm{M}_{\mathrm{BSFL}}\right)$, and the production of larvae biomass $\left(\mathrm{Q}_{\mathrm{BSF}}\right)$. Other parameters that influence the profit in a less significant manner are the price of labour $\left(P_{L}\right)$, the labour requirements $(L)$, initial investments $(I)$, and disposal costs $\left(P_{D}\right)$. Parameters concerning the price of frass $\left(P_{F}\right)$, the quantity of frass $\left(Q_{F}\right)$, the price of water $\left(P_{W}\right)$, water requirements $(W)$, the price of electricity $\left(P_{E}\right)$, and the electricity requirements seem to have the least impact on profits.

In our first model, where complete certainty in the parameters was assumed, our best guess scenarios for producing live and dried BSF larvae returned a negative yearly profit $(-€ 24,014$ and - $€ 58,957$, respectively). Break-even point analyses, show how much individual parameters have to change, in order to reach the point that turns this profit positive. So, depending on how a specific business model deviates from our best guess, a positive profit could be attained. Our second model assumes uncertainty in the values attributed to certain parameters in a Monte Carlo inspired approach. This model shows that selling live larvae has a higher probability of being profitable compared to dried larvae, when margins of dried and live BSF larvae are assumed to be equal. In our low uncertainty scenarios, the probabilities for positive profits were highest compared to similar medium and high uncertainty scenarios.

In conclusion, whether or not processing pig manure with BSF larvae is positive, depends on the specific business model of a farmer. Business models selling live larvae are more likely to be profitable in the explored scenarios. Furthermore, a higher margin leads to a higher probability of positive profits. For profitable business models it is important to try to negotiate a sufficiently low cost price of starter larvae and a high enough sales price of live or dried BSF larvae. Changes in other parameters are less impactful on profit. An alternative method to increase profits is to breed your own starter larvae, if you can manage to do that at a lower cost compared to the cost price when buying them. Alternatively, one can mix pig manure with other more nutritious waste streams in order to try and grow their BSF larvae better, thus increasing biomass production. Furthermore, it is important to note, that currently it is not yet legal to raise BSF larvae on any kind of animal manure. 


\section{Samenvatting}

De vraag naar voedings- en voederproducten groeit door een groeiende wereldbevolking. Daarom wordt er gezocht naar alternatieve methodes om voedings- en voedermiddelen te creëren, die het milieu en de huidige voedings- en voederbronnen minder onder druk te zetten (Smetana et al., 2019; Verbeke et al., 2015). Eén van de alternatieven waar toenemende aandacht voor is, is de toepassing van black soldier fly (BSF) larven (ook wel zwarte soldatenvlieg genoemd) op reststromen. In de context van de biobased economy, zetten BSF larven reststromen om naar waardevolle insectenbiomassa en organische meststof (frass). Het toepassen van BSF larven op mest heeft de potentie om kringlopen in de landbouw te sluiten (Bortolini et al., 2020). Dit rapport kijkt naar het winstgevendheidpotentieel van BSF larven gekweekt op varkensmest op het niveau van de individuele boer. Een gemiddelde vleesvarkensboer in Nederland moet de varkensmest van 1671 varkens verwerken (Wageningen University, 2020). Dit betekent dat er jaarlijks ongeveer $900.000 \mathrm{~kg}$ aan natte varkensdrollen verwerkt moet worden op een gemiddeld Nederlands varkensbedrijf. Als deze mest verwerkt zou worden door BSF larven, zou dit resulteren in ongeveer $89.000-104.000 \mathrm{~kg}$ aan levende BSF larven per jaar. Deze zouden kunnen worden gedroogd en dan ruwweg $22.000-26.000 \mathrm{~kg}$ aan gedroogde insectenbiomassa opleveren. Verder zou de mest worden omgezet naar $166.000-170.000 \mathrm{~kg}$ gedroogde frass per jaar.

De winstpotentie van BSF larven op varkensmest wordt het meest beïnvloed door een paar parameters. De grootste invloed komt van de kostprijs van starterslarven $\left(P_{s I}\right)$, de verkoopprijs van gedroogde/levende larven $\left(\mathrm{P}_{\mathrm{BSF}}, \mathrm{P}_{\mathrm{BSF}}\right.$ ), de marges van gedroogde/levende larven $\left(\mathrm{M}_{\mathrm{BSF}}, \mathrm{M}_{\mathrm{BSFL}}\right)$ en de productie van larven biomassa $\left(\mathrm{Q}_{\mathrm{BSF}}\right)$. Andere parameters die de winst beïnvloeden, zij het in mindere mate, zijn de arbeidsprijs $\left(P_{L}\right)$, de benodigde arbeidsuren $(L)$, de initiële investeringen (I) en de mestafvoerkosten $\left(P_{D}\right)$. Parameters gelinkt aan de frassprijs $\left(P_{F}\right)$, de hoeveelheid frass $\left(Q_{F}\right)$, de waterprijs $\left(P_{W}\right)$, waterverbruik $(W)$, de elektriciteitsprijs $\left(P_{E}\right)$ en elektriciteitsverbruik $(E)$ lijken de minste invloed op winst te hebben.

In het eerste model wordt een complete zekerheid van parameters aangenomen. De best guess scenario's voor het produceren van levende en gedroogde BSF larven resulteren in een negatieve jaarlijkse winst ( $€ 24,014$ en - $€$ 58,957, respectievelijk). Break-even point analyses geven aan hoeveel individuele parameters zouden moeten veranderen in de scenario's om het omslagpunt naar een positieve winst te bereiken. Dus, als een specifiek bedrijfsplan gunstig afwijkt van onze best guess, zou een positieve winst mogelijk zijn. Het tweede model neemt aan dat er onzekerheid is in de waarden toegekend aan bepaalde parameters, in een Monte Carlo geïnspireerde aanpak. Dit model laat zien dat de verkoop van levende larven een hogere kans heeft om winstgevend te zijn in vergelijking met de verkoop van gedroogde larven, wanneer wordt aangenomen dat de marges voor beide producten gelijk zijn. In de scenario's met de laagste onzekerheid, was de kans op positieve winsten was het hoogst in vergelijking met gelijksoortige medium en hoge onzekerheid scenario's.

Samengevat, of het verwerken van varkensmest met BSF larven een positief winstresultaat oplevert, hangt af van het specifieke business model van een boer. Business modellen die levende larven verkopen, zijn vermoedelijk vaker winstgevend, op basis van de verkende scenario's. Daarnaast leidt een hogere marge tot een hogere kans op positieve winsten. Business modellen met een lage kostprijs van starterslarven en een hoge verkoopprijs van hun producten hebben een grotere kans om winstgevend te zijn. Veranderingen in andere parameters hebben minder invloed op de winst. Een alternatieve methode om de winst te verhogen, is om eigen starterslarven te kweken, zolang dat tegen lagere kosten kan in vergelijking met het inkopen van de starterslarven na onderhandeling. Daarnaast zou varkensmest ook nog gemengd kunnen worden met alternatieve reststromen, die rijker in voedingsstoffen zijn en waar BSF larven beter op groeien, om zo de productie van larven te verhogen. Op dit moment is het nog niet wettelijk toegestaan om BSF larven te kweken op dierlijke mest en te verkopen als voederproduct. 


\section{Introduction}

The demand for feed and food resources is likely to increase substantially the coming decades, as the world population grows and economic development changes consumer preferences. This increased demand for feed and food products will increase its pressure on the environment, food resources and feed resources accordingly (Smetana et al., 2019; Verbeke et al., 2015). As pressure on food and feed resources increases, alternative food and feed resources are in high demand. Expanding the current food production system raises environmental concerns with regards to land use pressure, soil eutrophication and greenhouse gas emissions leading to climate change (Rustad, 2016). Insects are often seen as a potential solution for filling the protein gap for feed and food resources in a more sustainable manner compared to other animal protein sources (Niyonsaba et al., 2021; Smetana et al., 2019). In particular, there seems to be an increasing interest in the utilization of black soldier fly (BSF) larvae.

BSF larvae are one of the insect species garnering a lot of interest. BSF larvae have a relatively short life cycle, approximately 40 days for the complete life cycle depending on food availability and its environment (Coudron et al., 2018) and are not known to be vectors of disease (Bortolini et al., 2020). The main interest in BSF larvae is due to their ability to convert animal manure and other waste streams relatively quickly into a high quality insect biomass which is rich in proteins and fat (see figure 1.1). For example, the fat fraction contains lauric acid, which has been described to have health improving characteristics for livestock (Spranghers, 2017). This biomass can be used as high quality animal protein feedstuff for livestock or aquaculture (Bortolini et al., 2020; Newton et al., 2005; Parodi et al., 2020; Rustad, 2016; Smetana et al., 2019).

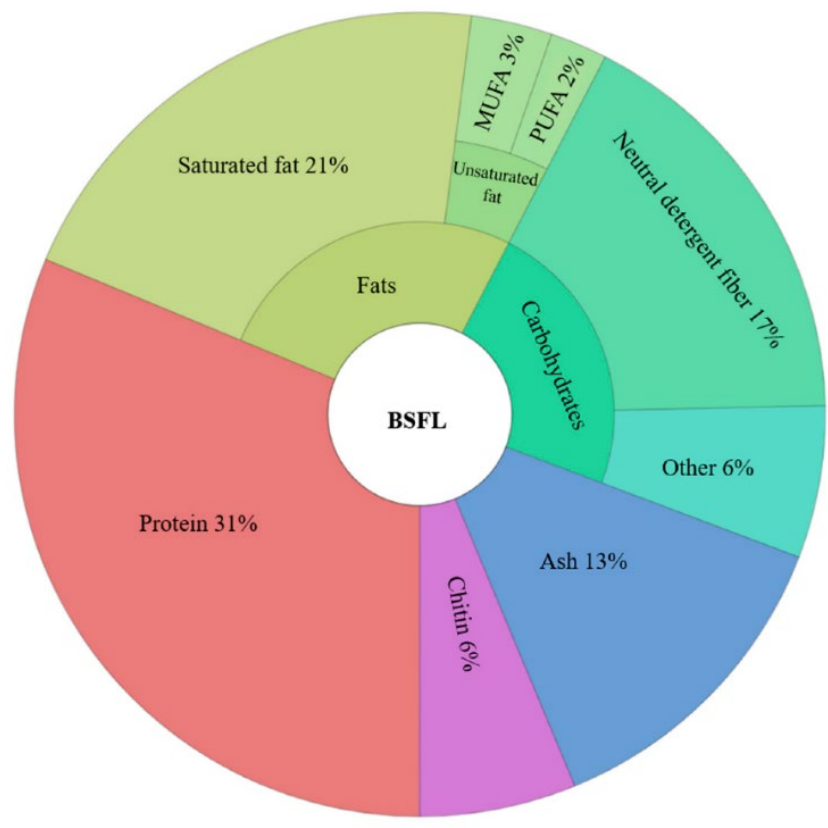

Annex $1 \quad$ Figure 1.1 Proximate composition of BSF larvae based on dry weight (Ravi et al., 2020)

Besides producing insect biomass, BSF larvae also have the potential to effectively convert animal manure and other waste streams into frass (insect feces), which is a high quality fertilizer (Bortolini et al., 2020; T. Liu et al., 2019; Newton et al., 2005). Converting waste streams into frass allows for natural recycling of nutrients and reduces the loss of important soil nutrients (Newton et al., 2005). On top of that it also reduces the volume of waste and seems to lower the presence of pathogens (Bortolini et al., 2020). Frass is an alternative to regular composting, and reduces the chances of spreading of disease and odors (Liu et al., 2019).

BSF larvae seem to have the potential to help facilitate closing loops within agri-food supply chains, thus facilitating a more circular agricultural landscape (Bortolini et al., 2020). Currently, there is an excess 
of manure in the Netherlands, leading to a situation where a negative value is attached to manure. However, manure contains valuable nutrients. By applying BSF larvae to manure, it is possible to upgrade manure waste streams as part of the biobased economy (ACRRES, n.d.). Valuable nutrients become available for the improvement of soil quality and the production of insect biomass, contributing to circularity by converting animal manure back into high quality feedstuff and organic fertilizer.

In light of maximizing the circularity potential of insects and BSF larvae, some steps in legislation have been made within the EU (see figure 1.2). Since 2017, insect protein is allowed as feed for aquaculture. Since then, black soldier flies are also allowed as feed for non-ruminant livestock such as chickens and pigs (Protix, n.d.) and as feed for pets (IPIFF, 2020). Since June 2021, animal and insect meal is allowed to be used as feedstuff (Lamers, 2021). Since August 2021, the European Union has authorized the use of processed animal proteins derived from insects (insect PAPs) in poultry and pig feed. However, while black soldier fly larvae can currently be fed to pigs, chickens, pets and fish, there are still restrictions on the waste streams on which these BSF larvae are allowed to be raised (see figure 1.2). Currently, it is legal to raise black soldier fly larvae on vegetal waste and former food wastes that are considered vegetal, dairy or eggs. However, it is not legal to raise black soldier fly larvae on meat and fish waste, catering waste, slaughterhouse products and animal manure (IPIFF, 2020). Currently, there are experiments being done that research the feed safety implications of raising BSF larvae on animal manure, due to its potential for circularity and the disadvantages of the current way of manure disposal (Wageningen University, 2019). So, it might be possible that legislation will change in the future.

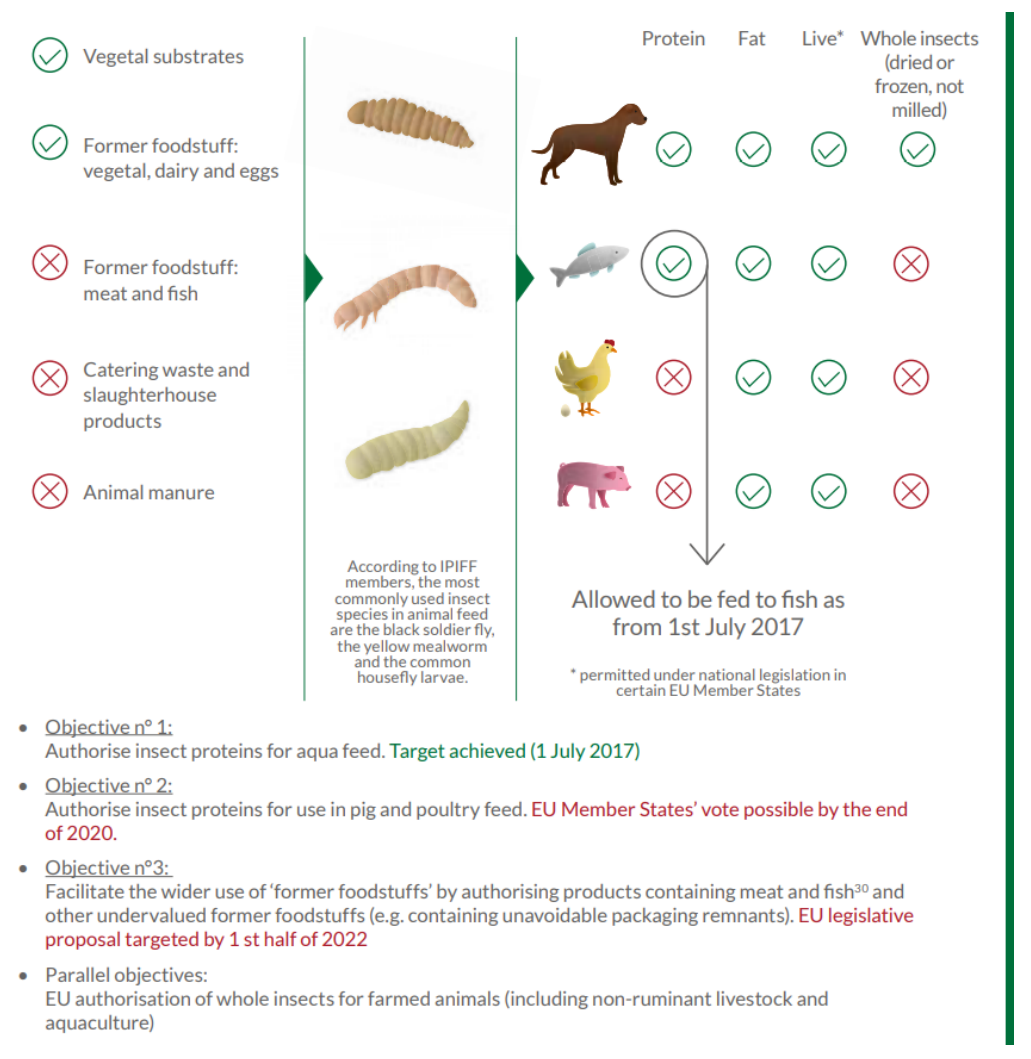

Annex 2 Figure 1.2 IPIFF EU Policy Roadmap on the use of insects in animal feed (May 2020) (IPIFF, 2020). Note: as of August, 2021, has authorized the use of processed animal proteins derived from insects (insect PAPs) in poultry and pig feed.

In the Netherlands, the goal is to be completely circular by 2050 . One of the goals is to close nutrient cycles, by recuperating them from waste streams (Rijksoverheid, 2016). As environmental concerns grow, pressure is added to farmers to become more sustainable and circular. For example, calls to cut the number of livestock in half have become more prominent in the Netherlands. Therefore, if allowed in the future, using BSF larvae to process manure would be a great step to increase the sustainability and circularity of individual farmers. In order for that to be a viable plan, producing black soldier flies needs to be profitable or at least break even. If profitable, it would also provide individual farmers with an extra diversified source of income. This income could come from selling BSF larvae and/or frass 
produced by BSF larvae and from a reduction in manure disposal costs. This report explores whether it would be profitable for pig farmers to produce black soldier fly larvae on pig manure at farm level, if producing BSF larvae raised on manure would be legal in the future. 


\section{Explanation of the calculation models}

In order to explore the profitability of using BSF larvae to process pig manure, two calculation models were build and used: One model which assumes complete certainty in its parameter inputs (model A), and one model which takes into account some uncertainty for specific parameter values, by using a Monte Carlo inspired approach (model B).

\subsection{Model A: A calculation tool for the profitability of black soldier flies on an individual farmer level.}

Model $A$ is a calculation tool to calculate the profitability of applying black soldier flies to process the pig manure of an individual farmer. Model A assumes complete certainty in its parameter inputs for every scenario. It is possible to adjust the parameter values per scenario, but once the parameters have been chosen for a scenario, the model will return its key figures without taking into account any uncertainty about these parameter values. Many parameters have been given three levels to choose from: a low, medium and high level. These levels can be chosen by checking the corresponding box in the checkbox in the Dashboard of the Excel calculation tool. See appendix 1 for an overview of the parameters in the dashboard of the calculation tool.

After determining the parameter inputs for a scenario, the model returns key figures to determine the profitability of applying black soldier flies to process pig manure for an individual farmer. It returns the yearly revenues, costs, cashflows and profits of applying BSF larvae to process pig manure. It also returns a few financial metrics: the payback period, the internal rate of return (IRR), and the net present values for the two discount rates indicated in the dashboard. If you are unfamiliar with these terms, an overview of the definitions of these key financial metrics can be found in appendix 2 .

The model assumes farmers will buy starter larvae that can be directly applied to process pig manure. This model does not concern itself with the potential for farmers to breed and produce their own starter larvae. This is done because breeding their own starter larvae adds an extra step to the production process and complicates the production process, thus making it less likely for a farmer to incorporate this easily in its current farm routine. This model assumes a farmer will buy starter larvae, apply them to process pig manure in a semi-automated manner and subsequently sells its outputs without much processing aside from potentially drying.

The margins for the outputs of applying BSF larvae are set at $60 \%$ to indicate that the full final sales price might not completely go to the farmer, if the farmer is not the final link in the commodity chain. Furthermore this margin also takes into account a reduction from the final sales price due to unspecified costs related to sales such as energy costs related to drying larvae (if applicable) ${ }^{1}$, packaging and shipping costs. These costs were chosen to be incorporated as a margin, since these costs are very variable depending on the individual business model of the farmer. Furthermore, due to the innovative nature of applying BSF larvae to pig manure, the data that are available to determine these costs were limited. Therefore, it was decided to incorporate them as a percentage of the final sales price, instead of ignoring them. To summarize, the margin makes sure the following things are indirectly included and expressed as a percentage of the final sales price:

- Variable processing costs, such as energy costs related to drying.

- Variable marketing and logistics costs, such as packaging, shipping and customer management costs.

- To indicate that the final sales price, does not necessarily go to the farmer in full. Provided the farmer is not the final link in the commodity chain.

\footnotetext{
${ }^{1}$ Limited investments in drying equipment, was incorporated (i.e. as fixed costs)
} 
Furthermore, the depreciation period is set at 10 years. Labour costs for the farmer were set at $130 \%$ of the average gross hourly wage for agriculture (CBS, 2019). Based on internal experiments with BSF larvae an insect production cycle of 7 days was assumed (from starter larvae to full- grown larvae), as well as the required amount of starter larvae $(14.12 \mathrm{~kg} /$ tonne of wet pig manure). For the scenarios run in this report, a $100 \%$ of the manure of an average Dutch pig farm is assumed to be processed by the BSF larvae.

For model A five different scenarios are considered. First of all a best guess scenario, where $100 \%$ of the BSF biomass sold is dried. For this best guess scenario the parameter levels chosen are our current best guess to calculate the profitability of BSF larvae raised on pig manure. Secondly, a best guess live scenario is considered, where $100 \%$ of the produced BSF biomass is sold alive. The third scenario is the medium scenario, where all parameter levels were set to the medium level. The fourth scenario is the most favourable scenario, where all parameter levels were set in such a way that it would result in the highest possible profit. The fifth and final scenario is the least favourable scenario, where all parameter levels were set in such a way that it would result in the lowest possible profit.

\subsection{Model B: A Monte Carlo inspired calculation tool for the profitability of black soldier flies for on individual farmer level.}

While Model A assumes complete certainty for its parameters, Model B includes uncertainty for some of its parameters. With new and relatively unexplored farming techniques, such as applying BSF larvae to pig manure, some uncertainty regarding parameters remains. For example, the exact sales price of dried BSF larvae has a wide range of reported values in the literature. To incorporate this uncertainty in our input parameters, model B uses a Monte Carlo inspired approach to evaluate the profitability of applying black soldier flies to process the pig manure.

A Monte Carlo inspired approach assigns a distribution for parameter values, rather than one specific value. In this model, the distribution for each parameter value is determined by the minimum and maximum values from model $A$. For each parameter in model $A$ with 3 potential values (the value level could be chosen by ticking the corresponding checkbox), a normal distribution was assumed. The minimum level value corresponds with the point three standard deviations below the mean in the normal distribution. The maximum level value corresponds with the point three standard deviations above the mean of the normal distribution. The mean is determined as the middle point between the minimum and maximum values. The standard deviation is determined by dividing the absolute difference between the mean and the minimum by 3 . When assuming a normal distribution, it is expected that $99.7 \%$ of all parameter values fall in between the minimum and maximum value (see figure 2.2.1).

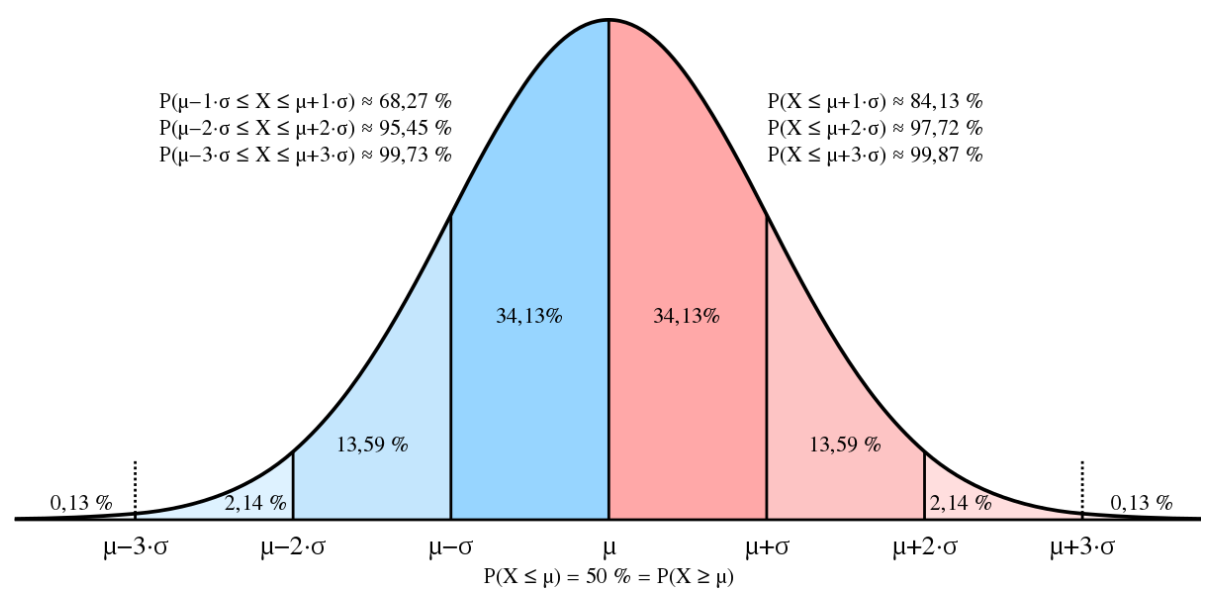

Annex $3 \quad$ Figure 2.2.1 Normal distribution (Kowarschick, 2012). 
The next step for model $B$ is to simulate the profitability for a single farmer for a given scenario 10,000 times (called 10,000 runs). In each individual run the parameter values are randomly picked from its corresponding normal distribution. After each parameter value is randomly picked, the model calculates the profitability, revenues, costs and other key financial metrics for each individual run. Taking all these 10,000 runs together, results in a simulation of the given scenario. The simulation returns the probability that the yearly profits of applying BSF larvae to manure fall in a certain category. For example, it can return the probability that the yearly profits are positive for a given scenario. The probabilities can also be calculated for other ranges of the parameter. For instance, the probability the profitability is larger than $€ 100,000$ per year. The model also returns probabilities for the values of other key figures and potential magnitudes, such as revenues, costs, cashflows, payback periods and internal rates of return (IRR).

By structuring the parameter distributions this way, renditions are most likely to pull a value close to the mean of the given normal distribution. In this case, the mean of the given normal distribution corresponds to the medium level of model $A$.

Due to this, three different scenarios were run for model B. A high uncertainty scenario where all parameters were assumed to be uncertain and assigned a normal distribution, based on their minimum and maximum values assigned. A medium uncertainty scenario, where uncertainty regarding the sales price of frass (set at $€ 20$ per tonne (Ecocultworms, 2020)) and the cost price of starter larvae (set at $€ 14.29$ per kg (ACRRES 2021c, Internal communication) was eliminated. This was done, because the mean of the randomly picked values in model B deviates significantly from the parameter value in the best guess scenario of model $A$. Besides, these the cost price of starter larvae also turned out to be very elastic and sensitive based on our elasticity sensitivity analysis of model A. Finally, a very low uncertainty scenario was also run. Uncertainty regarding investments and labour requirements was eliminated by locking them to their minimum levels. These two parameters were chosen, because the best guess of model A deviates significantly from the mean of the randomly picked values of model B. These parameters showed an inelastic, but potentially still sizeable impact based on our elasticity sensitivity analysis of model $A$.

Furthermore, the assumptions from model A still hold apart from the uncertainty assumptions. 


\section{Results of the calculation models}

The results in this chapter are based on assumptions about an average Dutch pig farmer. The average Dutch pig farm has to process the pig manure of 1671 adult pigs (Wageningen University, 2020). This means that approximately $900,000 \mathrm{~kg}$ of wet pig manure has to be processed each year. If one would process this with BSF larvae, this would result in approximately $89,000-104,000 \mathrm{~kg}$ of live BSF larvae per year, which could be turned into roughly $22,000-26,000 \mathrm{~kg}$ of dried insect biomass. The dried frass potential lies between $166,000-170,000 \mathrm{~kg}$ frass per year. The dry matter percentage of BSF larvae is $25 \%$ of the live weight.

\subsection{Results Standard scenarios model A}

For the input values of model A, see appendix 3. For additional results of the scenarios, see appendix 4

\subsubsection{Best Guess Scenario (A)}

For the best guess scenario, the yearly profit is $-€ 58,957$. Due to the negative yearly cashflow and profit there is no viable payback period or positive internal rate of return. Furthermore, the NPVs of this investment are also negative, as expected.

Table 1 Yearly profits, costs and revenues for best guess scenario A

\begin{tabular}{lll} 
Profit, costs and revenues (A) per year & & \\
Total Yearly Revenues & $€$ & 195,935 \\
\hline Total Yearly Costs & $€$ & 254,893 \\
\hline Total Yearly Profits & $€$ & $-58,957$ \\
\hline
\end{tabular}

Table 2 Financial figures for best guess scenario $A$

\begin{tabular}{lll} 
Financial figures (A) & & $-39,622$ \\
\hline Cashflow per year & $€$ & 193,350 \\
\hline Initial investment & & \\
\hline & FALSE \\
\hline Payback period (in years) & FALSE \\
\hline Internal rate of return (IRR) & $€$ & $-531,335$ \\
\hline Net present value (10 years, 3\%) & $€$ & $-471,639$ \\
\hline Net present value $(10$ years, 7\%)
\end{tabular}

This negative profit seems mainly due to the relatively high cost price of starter larvae ( $P_{s L}$ ). The revenues from sales of dried BSF larvae alone $(€ 175,869)$ are not enough to cover for the costs of starter larvae $(€ 182,015)$ in this scenario.

In general, if we want the revenues of dried BSF larvae to cover the costs of starter larvae completely, the price of $1 \mathrm{~kg}$ of dried BSF larvae ( $\mathrm{P}_{\mathrm{BSF}}$ ) and its margin ( $\mathrm{M}_{\mathrm{BSF}}$ ) need to be high enough. In order to cover the complete starter larvae costs exactly with revenue from dried BSF sales, the price of dried BSF larvae multiplied by its margin ( $\mathrm{P}_{\mathrm{BSF}}{ }^{*} \mathrm{M}_{\mathrm{BSF}}$ ), needs to be 1.9 times higher than the cost price of starter larvae ( $\left.P_{S L}\right)$. Formula (1) shows the break-even point where the costs of starter larvae are equal to the revenues of dried BSF sales.

$\mathrm{PSL}_{\mathrm{SL}}=1.9 \mathrm{P}_{\mathrm{BSF}} * \mathrm{MBSF}_{\mathrm{BS}}$ 
The overall profit can still be positive if the costs of starter larvae are higher than the revenues of dried BSF larvae, as long as the difference and other costs are compensated by the revenue streams of the other output (frass). But, in the best guess scenario, the overall profit is negative.

Therefore, in order to make the profit of this investment at least break even, some parameters would need to change in our best guess scenario. Table 3 shows the break-even point values (BEP values) for our best guess scenario selling dried BSF larvae, given all other parameters stay equal (i.e. ceteris paribus). Table 3 shows that, a cost price of $€ 9.65$ per $\mathrm{kg}$ of live starter larvae would be enough to break even in our best guess scenario, instead of the assumed cost price of $€ 14.29$ per $\mathrm{kg}$. The assumed cost price is based on smaller quantities (van Schelt, 2021, personal communication), and it might not be inconceivable that a lower cost price of starter larvae could be negotiated for repeated larger-scale orders.

However, one could also look at how much the revenue should increase in order to break even. When looking at the sales price of dried BSF larvae ( $\mathrm{PBSF}_{\mathrm{BS}}$ ), a price of $€ 16.16$ per $\mathrm{kg}$ of dried BSF larvae would also lead to a break-even point, compared to the scenario value of $€ 12.10$ per $\mathrm{kg}$. Similarly, increasing the margin from $60 \%$ to $80 \%$ will also lead to a break-even point. Thus if a business is set up in such a way where sales costs are low and they deliver directly to the consumer, a positive profit under the best guess scenario is more likely.

Similarly, one could also look at an increase in frass revenue to break even. In our best guess scenario the price of frass $\left(P_{F}\right)$ would need to be $€ 603.79$ per tonne in order to break even. This seems unlikely compared to the current price of worm compost (vermicompost/worm casts/worm humus) of $€ 20$ per tonne (Ecocultworms, 2020). However, in some literary studies, higher frass prices than $€ 603.79$ have been mentioned. Ites et al. (2020), hypothesized a frass price of $€ 690$ per tonne, while Caruso et al. (2013), cited a frass price between $€ 590$ and $€ 850$ per tonne. These prices seem extremely high, but are not unprecedented in the literature. These prices are of course also dependent on the sales/packaging volumes, marketing and the end markets.

Lastly, if legislation surrounding manure disposal changes, for example due to stricter climate legislation, using BSF larvae to process pig manure might become more profitable. If manure disposal costs would increase from $€ 20$ to $€ 85.34$ per tonne of pig manure, the current best guess scenario would break even.

Table 3: Break-even points values for best guess scenario $A$

\begin{tabular}{lll} 
Break-even parameters (A) & BEP Value & Scenario Value \\
Cost price of starter larvae (PS) & $€ 9.65 / \mathrm{kg}$ & $€ 14.29 / \mathrm{kg}$ \\
\hline Price of dried larvae (PBS) & $€ 16.16 / \mathrm{kg}$ & $€ 12.10 / \mathrm{kg}$ \\
\hline Price of frass $\left(\mathrm{PF}_{\mathrm{F}}\right)$ & $€ 603.79 /$ tonne & $€ 20 /$ tonne \\
\hline Cost of manure disposal (PD) & $€ 85.34 /$ tonne & $€ 20 /$ tonne \\
\hline Margin dried BSF (MSF) & $80 \%$ & $60 \%$
\end{tabular}




\subsubsection{Best Guess Live Scenario (B)}

This analysis mostly concerns itself with a business model that processes pig manure and sells dried BSF larvae as an end product. This end product has a wider range of applications (compared to live BSF larvae) and is currently the standard. However, there are situations where one could sell live BSF larvae. An example is the direct distribution and sales of live larvae to chicken farmers as chicken feed. Whether selling live larvae is more profitable compared to selling dried larvae, depends on the price of live larvae $\left(P_{B S F L}\right)$, the price of dried larvae $\left(P_{B S F}\right)$, and their respective margins $\left(M_{B S F L}, M_{B S F}\right)$. When drying $B S F$ larvae, water evaporates and thus results in a lower weight. One kilogram of live larvae (produced on pig manure, this varies with input substrate) results in approximately 250 grams of dried larvae due to its dry matter percentage (DMBSFL $=0.25$ ). If formula $(2)$ holds, it is more profitable to sell live BSF larvae compared to dry BSF larvae. Thus, $\mathrm{PBSF}_{\mathrm{BSF}}$ needs to be at least 4 times as high as $\mathrm{PBSF}_{\mathrm{BS}}$, for dried larvae to be more profitable than live larvae, assuming equal margins for dried and live BSF larvae.

$\frac{P_{B S F L} * M_{B S F L}}{P_{B S F} * M_{B S F} * D M_{B S F L}}>1$

Looking at our best guess scenario, selling dried larvae is only more profitable compared to selling live larvae for a low $\mathrm{P}_{\mathrm{BSFL}}$. For a medium and high $\mathrm{P}_{\mathrm{BSFL}}$, selling live larvae is more profitable. For a high $\mathrm{P}_{\mathrm{BSFL}}$, the yearly profit is positive $(€ 41,452)$ and has a high internal rate of return of $29 \%$.

Table 4 Profits, costs and revenues for the best guess live scenarios $B$

\begin{tabular}{|c|c|c|c|}
\hline $\begin{array}{l}\text { Profit, costs and revenues (B) per } \\
\text { year }\end{array}$ & Low PBSFL & Medium PBSFL & High PBSFL \\
\hline Total Yearly Revenues & $€ 165,413$ & $€ 230,879$ & $€ 296,344$ \\
\hline Total Yearly Costs & $€ 254,893$ & $€ 254,893$ & $€ 254,893$ \\
\hline Total Yearly profits & $-€ 89,480$ & $-€ 24,014$ & $€ 41,452$ \\
\hline
\end{tabular}

Table 5 Financial figures for live scenarios B

\begin{tabular}{|c|c|c|c|}
\hline Financial figures & LOW PBSFL & Medium PBSFL & High PBSFL \\
\hline Cashflow per year & $-€ 70,145$ & $-€ 4,679$ & $€ 60,787$ \\
\hline Payback period (in years) & FALSE & FALSE & 3.18 \\
\hline Net present value (10 years, 3\%) & $-€ 791,700$ & $-€ 233,263$ & $€ 325,174$ \\
\hline Net present value (10 years, 7\%) & $-€ 686,018$ & $-€ 226,213$ & $€ 233,591$ \\
\hline
\end{tabular}

If the medium PBSF would be assumed to be the best guess for live scenarios, table 6 shows the corresponding break-even point values. It shows that if the sales price of live BSF larvae is higher than $€ 4.03$, the profit will be positive in this scenario. Furthermore, it also shows smaller changes for the other parameters are required to break even, compared to the best guess scenario with dried larvae (A). Thus, smaller changes are able to turn this scenario into a scenario with positive profits, compared to best guess scenario $A$. 
Table 6 Break-even point values for best guess scenario B (based on medium PBSFL)

\begin{tabular}{lll} 
Break-even parameters (B) & BEP Value & Scenario Value \\
\hline Cost price of starter larvae ( $\left.\mathrm{P}_{\mathrm{SL}}\right)$ & $€ 12.40 / \mathrm{kg}$ & $€ 14.29 / \mathrm{kg}$ \\
\hline Price of live BSF larvae ( $\left.\mathrm{P}_{\mathrm{BSFL}}\right)$ & $€ 4.03 / \mathrm{kg}$ & $€ 3.63 / \mathrm{kg}$ \\
\hline Price of frass $\left(\mathrm{P}_{\mathrm{F}}\right)$ & $€ 257.77 /$ tonne & $€ 20 /$ tonne \\
\hline Cost of manure disposal $\left(\mathrm{P}_{\mathrm{D}}\right)$ & $€ 46.62 /$ tonne & $€ 20 /$ tonne \\
\hline Margin live BSF (MBSF) & $67 \%$ & $60 \%$
\end{tabular}




\subsubsection{Medium Scenario (C)}

In the medium scenario all parameters are set to their medium values. With the input values assigned to these parameters, this results in a negative yearly profit of - $€ 111,727$. Both the yearly profit and its financial figures indicate that this is not a financially viable investment. Most revenue comes from the sales of dried BSF larvae ( $€ 175,869)$, however the costs of buying starter larvae are already higher than the revenue from selling dried BSF larvae $(€ 218,418)$. In fact, the costs of starter larvae are even higher than total revenues $(€ 210,074)$.

Table 7 Profits, costs and revenues for medium scenario $C$

\begin{tabular}{llc} 
Profit, costs and revenues (C) per year & & \\
Total Yearly Revenues & $€$ & 210,074 \\
\hline Total Yearly Costs & $€$ & 321,801 \\
\hline Total Yearly Profits & $€$ & $-111,727$ \\
\hline
\end{tabular}

Table 8 Financial figures for medium scenario $C$

\begin{tabular}{lll} 
Financial figures (C) & & $-82,737$ \\
\hline Cashflow per year & $€$ & 289,893 \\
\hline Initial investment & & \\
\hline & FALSE \\
\hline Payback period (in years) & FALSE \\
\hline Internal rate of return (IRR) & $€$ & $-995,658$ \\
\hline Net present value (10 years, 3\%) & $€$ & $-871,005$ \\
\hline Net present value $(10$ years, 7\%)
\end{tabular}

The break-even point parameters in table 9 show that this scenario could still be turned positive if certain parameters would be changed, given all other parameters stay the same. If the cost price of starter larvae is lowered from $€ 17.14$ to $€ 8.35$, the profit would reach its break-even point. Similarly if the values assigned to the prices of the outputs would be significantly higher, this scenario could still break even. If the margin of dried BSF larvae is $98 \%$, it would also result in a break-even point, where the profit is zero.

Table 9 Break-even point values for medium scenario C

\begin{tabular}{lll} 
Break-even parameters (C) & BEP Value & Scenario Value \\
Cost price of starter larvae (PS) & $€ 8.35 / \mathrm{kg}$ & $€ 17.14 / \mathrm{kg}$ \\
\hline Price of dried BSF larvae (PBS) & $€ 19.80 / \mathrm{kg}$ & $€ 12.10 / \mathrm{kg}$ \\
\hline Price of frass $\left(\mathrm{P}_{\mathrm{F}}\right)$ & $€ 1266.97 /$ tonne & $€ 160 /$ tonne \\
\hline Cost of manure disposal (PD) & $€ 143.90 /$ tonne & $€ 20 /$ tonne \\
\hline Margin dried BSF (MSF) & $98 \%$ & $60 \%$ \\
\hline
\end{tabular}




\subsubsection{Most favourable scenario (D)}

This scenario set all parameters to the level that would result in the highest possible profit. With the input values assigned to these parameter levels, this results in a positive yearly profit of $€ 77,829$. The financial numbers and metrics also show a financially viable investment, with a payback period of approximately 2 years, and an internal rate or return (IRR) of $48 \%$. Similarly, the NPV for both discount rates is very positive.

Table 10 Profits, costs and revenues for most favourable scenario $D$

\begin{tabular}{lll} 
Profit, costs and revenues (D) per year & $€$ & 328,282 \\
\hline Total Yearly Revenues & $€$ & 250,453 \\
\hline Total Yearly Costs & $€$ & 77,829 \\
\hline Total Yearly Profits & $€$ & \\
\hline
\end{tabular}

Table 11 Financial figures for most favourable scenario $D$

\begin{tabular}{|c|c|c|}
\hline \multicolumn{3}{|l|}{ Financial figures (D) } \\
\hline Cashflow per year & $€$ & 97,792 \\
\hline Initial investment & $€$ & 199,632 \\
\hline Payback period (in years) & 2.04 & \\
\hline Internal rate of return (IRR) & $48 \%$ & \\
\hline Net present value (10 years, 3\%) & $€$ & 634,553 \\
\hline Net present value (10 years, $7 \%$ ) & $€$ & 487,218 \\
\hline
\end{tabular}

The break-even point values in table 12 show that parameter values have to change quite a bit before the yearly profit would hit zero, ceteris paribus. Interestingly, in this scenario the profit would still be positive when the price of frass $\left(P_{F}\right)$ is 0 , ceteris paribus. Even more curious is that in this scenario, producing BSF larvae is so profitable, a farmer would be willing to pay up to $€ 64.25 /$ tonne in order to keep their pig manure, and process it with BSF larvae. The break-even values show that even in the most favourable scenario possible, the margin of dried BSF larvae ( $M_{B S F}$ ) needs to be higher than $43 \%$ in order to have a positive profit. Also, they indicate the maximum or minimum parameter values required to turn a profit if all other parameters are set to the most optimistic scenario. As such, if the cost price of starter larvae $\left(P_{\mathrm{SL}}\right)$ is higher than $€ 20.39$, there is no scenario that will lead to a positive yearly profit.

Table 12 Break-even point values for most favourable scenario $D$

\begin{tabular}{lll} 
Break-even parameters (D) & BEP Value & $\begin{array}{l}\text { Scenario } \\
\text { Value }\end{array}$ \\
\hline Cost price of starter larvae (PL) & $€ 20.39 / \mathrm{kg}$ & $€ 14.29 / \mathrm{kg}$ \\
\hline Price of dried larvae (PBS) & $€ 12.74 / \mathrm{kg}$ & $€ 17.70 / \mathrm{kg}$ \\
\hline Price of frass $\left(\mathrm{PF}_{\mathrm{B}}\right)$ & $-€ 460.60 /$ tonne & $€ 300 /$ tonne \\
\hline Cost of manure disposal (PD) & $-€ 64.25 /$ tonne & $€ 22 /$ tonne \\
\hline Margin dried BSF (MSF) & $43 \%$ & $60 \%$ \\
\hline
\end{tabular}




\subsubsection{Least favourable scenario $(E)$}

The least favourable scenario sets all parameters to the level which would result in the lowest possible profit, while still having a positive frass price. This scenario results in a negative yearly profit of

- $€ 289,600$. Thus the least favourable scenario is not a financially viable investment.

Table 13 Profit, costs and revenues for least favourable scenario $E$

\begin{tabular}{llc} 
Profit, costs and revenues (E) per year & & \\
Total Yearly Revenues & $€$ & 105,193 \\
\hline Total Yearly Costs & $€$ & 393,792 \\
\hline Total Yearly Profits & $€$ & $-288,600$ \\
\hline
\end{tabular}

Table 14 Financial figures for least favourable scenario $E$

\begin{tabular}{|c|c|c|}
\hline \multicolumn{3}{|l|}{ Financial figures (E) } \\
\hline Cashflow per year & $€$ & $-249,956$ \\
\hline Initial investment & $€$ & 386,436 \\
\hline Payback period (in years) & \multicolumn{2}{|c|}{ FALSE } \\
\hline Internal rate of return (IRR) & \multicolumn{2}{|c|}{ FALSE } \\
\hline Net present value (10 years, low discount rate) & $€$ & $-2,518,611$ \\
\hline Net present value (10 years, high discount rate) & $€$ & $-2,142,022$ \\
\hline
\end{tabular}

The break-even point values in table 15 show the values which would turn this scenario's profit from negative to zero. Since these are the break-even point values for the least favourable scenarios, these values would result in a positive profit for all other scenarios that are even slightly more optimistic. So, if the costs of manure disposal $\left(P_{D}\right)$ should ever increase to more than $€ 337.84$ per tonne of wet manure, applying BSF larvae would result in a positive yearly profit according to this calculation model. Remarkably, in this scenario a negative cost price is required to break even, ceteris paribus, which is impossible. Similarly it is impossible to have a margin over $100 \%$. So this scenario cannot break even by solely changing the cost price of starter larvae $\left(P_{S L}\right)$ or applying a higher margin (MBSF).

Table 15 Break-even point values for least favourable scenario $E$

\begin{tabular}{lll} 
Break-even parameters (E) & BEP Value & $\begin{array}{l}\text { Scenario } \\
\text { Value }\end{array}$ \\
Cost price of starter larvae (PSL) & $-€ 2.65 / \mathrm{kg}$ & $€ 20 / \mathrm{kg}$ \\
\hline Price of dried larvae (PSF) & $€ 28.08 / \mathrm{kg}$ & $€ 6.50 / \mathrm{kg}$ \\
\hline Price of frass $\left(\mathrm{P}_{\mathrm{F}}\right)$ & $€ 2915.94 /$ tonne & $€ 20 /$ tonne \\
\hline Cost of manure disposal $\left(\mathrm{P}_{\mathrm{D}}\right)$ & $€ 337.84 /$ tonne & $€ 18 /$ tonne \\
\hline Margin dried BSF (MSF) & $259 \%$ & $60 \%$
\end{tabular}




\subsection{Sensitivity analysis model A}

Elasticities measure the sensitivity of a chosen dependent variable to changes in their independent variables. In this case when we look at the elasticities of profit, we look at the sensitivity of profit to changes of specific parameters, given all other parameters do not change (i.e. ceteris paribus). Therefore, the elasticity of profit represents the expected profit percentage change, when the given parameter is changed by $1 \%$, ceteris paribus. The larger the absolute value of an elasticity, the larger its impact on profit. A negative elasticity indicates that if the corresponding parameter is increased, the profitability will decrease. A positive elasticity indicates that if the corresponding parameter is increased, the profitability will increase as well. Generally, elasticities with an absolute value larger than 1 are considered elastic. When a parameter is elastic, it means that profit is very sensitive to changes in this particular parameter. In that case, the profit is so sensitive, that it will change with a larger percentage change than the changed parameter itself. Thus, to determine which parameters impact the profitability of applying black soldier flies to pig manure the most, one can look at the elasticity of its parameters in the model.

\subsubsection{Overview of the Elasticities}

Table 16 Overview of the elasticities of profit per scenario

\begin{tabular}{|c|c|c|c|c|c|}
\hline Elasticities of profit & $\begin{array}{r}\text { A: Best } \\
\text { guess } \\
\text { scenario } \\
\text { (dried) }\end{array}$ & $\begin{array}{r}\text { B: Best guess } \\
\text { live scenario } \\
\text { (live) }\end{array}$ & $\begin{array}{l}\text { C: Medium } \\
\text { scenario (dried) }\end{array}$ & $\begin{array}{r}\text { D: Most } \\
\text { favourable } \\
\text { scenario } \\
\text { (dried) }\end{array}$ & $\begin{array}{r}\text { E: Least } \\
\text { favourable } \\
\text { scenario (dried) }\end{array}$ \\
\hline Price per kwh $\left(P_{E}\right)$ & -0.036 & -0.087 & -0.021 & -0.027 & -0.009 \\
\hline Price per m3 (Pw) & -0.090 & -0.220 & -0.023 & -0.003 & -0.018 \\
\hline Price per labour hour $\left(\mathrm{PL}_{\mathrm{L}}\right)$ & -0.783 & -1.922 & -0.589 & -0.594 & -0.318 \\
\hline Margin of dried larvae (M BSF ) & 2.983 & - & 1.497 & 3.576 & 0.300 \\
\hline Margin of live larvae (M $\left.\mathrm{MSFL}_{\mathrm{BF}}\right)$ & - & 8.779 & - & - & - \\
\hline Margin of frass $\left(M_{F}\right)$ & 0.034 & 0.084 & 0.089 & 0.385 & 0.002 \\
\hline Sales price dried larvae ( $\left.\mathrm{P}_{\mathrm{BSF}}\right)$ & 2.983 & - & 1.497 & 3.576 & 0.300 \\
\hline Sales price of live larvae ( $\left.P_{B S F L}\right)$ & - & 5.752 & - & - & - \\
\hline Sales price frass $\left(P_{F}\right)$ & 0.034 & 0.084 & 0.089 & 0.385 & 0.002 \\
\hline Cost price starter larvae (PSL) & -3.087 & -7.580 & -1.860 & -2.344 & -0.879 \\
\hline Disposal costs $\left(P_{D}\right)$ & -0.306 & 0.752 & 0.154 & 0.256 & 0.056 \\
\hline Initial investments (I) & -0.328 & -0.805 & -0.247 & -0.249 & -0.133 \\
\hline labour requirements $(\mathrm{L})$ & -0.783 & -1.922 & -0.589 & -0.594 & -0.318 \\
\hline Production of larvae biomass (QBSF) & 2.983 & 4.040 & 1.496 & 3.412 & 0.300 \\
\hline Production frass $\left(\mathrm{Q}_{\mathrm{F}}\right)$ & -0.179 & -0.439 & 0.089 & 0.223 & 0.002 \\
\hline $\begin{array}{l}\text { Electricity requirement per container } \\
\text { (E) }\end{array}$ & -0.036 & -0.087 & -0.021 & -0.027 & -0.009 \\
\hline Water requirement $(\mathrm{W})$ & -0.090 & -0.220 & -0.023 & -0.003 & -0.018 \\
\hline
\end{tabular}

Looking at these elasticities, a few things stand out. For best guess scenario A, the most elastic parameters are the cost price of the starter larvae $\left(P_{S L}\right)$, the profit margin of dried larvae (M $\left.M_{B S F}\right)$, the sales price of dried larvae ( $\mathrm{P}_{\mathrm{BSF}}$ ), and the production of larvae biomass ( $\left.\mathrm{Q}_{\mathrm{BSF}}\right)$. This is not completely unexpected, since the majority of the revenue in the best guess scenario (90\%) comes from the sales of dried larvae. Therefore, it is logical that the parameters influencing the production, sales price or margin of dried larvae influence the profit more than proportionally. Thus a $1 \%$ change in these parameters will lead to an expected profit change of more than $1 \%$.

Similarly, for best guess scenario A, the costs from starter larvae make up $71 \%$ of the costs. So, increasing the cost price of starter larvae will have a relatively large impact. Thus it is not surprising 
that this parameter is very elastic. Other parameters that have a noticeable influence on profitability, are the price of labour $\left(P_{L}\right)$ and labour requirements $(L)$. These parameters are inelastic, but a $1 \%$ change in either of these parameters would result in an expected profit percentage change of approximately $0.78 \%$.

Furthermore for best guess scenario $A$, parameters concerning the production of frass and its sales ( $P_{B S F}$, $\left.M_{B S F}, Q_{B S F}\right)$ are very inelastic and thus seem to have a relatively minor impact on profitability. The same goes for changes in manure disposal costs $\left(\mathrm{PD}_{\mathrm{D}}\right)$ and investments (I). Furthermore, the parameters surrounding utilities $\left(\mathrm{P}_{\mathrm{E}}, \mathrm{P}_{\mathrm{w}}, \mathrm{E}, \mathrm{W}\right)$ are even more inelastic.

Looking at best guess live scenario $\mathrm{B}$, some trends are similar to best guess scenario $\mathrm{A}$. The price and margins for the final end product $\left(\mathrm{P}_{\mathrm{BSFL}}, \mathrm{M}_{\mathrm{BSFL}}\right)$ are very elastic. Furthermore, the cost price of starter larvae is extremely elastic, even more than in scenario $A$. Utilities parameters $\left(P_{E}, P_{W}, E, W\right)$ and frass parameters ( $P_{B S F}, M_{B S F}, Q_{B S F}$ ) are also inelastic, although less so compared to scenario $A$. The parameters of investment $(I)$, and manure disposal costs $\left(P_{D}\right)$, while still inelastic, are much less inelastic compared to scenario $A$. However, one of the biggest differences with scenario $A$ is that in scenario $B$, labour requirements $(L)$ and the price of labour $\left(P_{L}\right)$ are also elastic and are thus relatively influential on the expected profit.

The elasticities for medium scenario $C$, follow the same trends as the elasticities of best guess scenario A. The same parameters that are elastic in scenario A, are also elastic in scenario C. However, these parameters seem to be slightly less elastic compared to best guess scenario $A$. All other parameters are even more inelastic compared to scenario $A$, except the frass parameters ( $P_{B S F}, M_{B S F}, Q_{B S F}$ ), which are slightly less inelastic compared to scenario A.

The elasticities of profit for the most favourable scenario D, also follow a similar trend compared to best guess scenario $A$. The most elastic parameters are once more linked to the cost price of starter larvae $\left(\mathrm{P}_{\mathrm{SL}}\right)$ and parameters concerning the sales and production of dried BSF larvae (MBSF, $\mathrm{P}_{\mathrm{BSF}}, \mathrm{Q}_{\mathrm{BSF}}$ ). However, these parameters are even more elastic compared to scenario A. Once more, the labour parameters are inelastic, but a $1 \%$ change in these parameters is still expected to result in a profit change of $0.59 \%$. All the other parameters are more inelastic compared to scenario $A$, except for the parameters linked to frass. Those parameters $\left(P_{F}, M_{F}\right.$, and $\left.Q_{F}\right)$ are less inelastic compared to best guess scenario A.

The elasticities for the least favourable scenario show something different than all other scenarios. Namely, none of the parameters are elastic, meaning that changing these parameters will not result in a proportionally large change in the profit. Still, we see that compared to the other parameters the cost price of starter larvae has the largest relative impact on profitability. Followed by the parameters linked to labour $\left(L, P_{L}\right)$ and the production and sales of dried larvae ( $\left.P_{B S F}, M_{B S F}, Q_{B S F}\right)$, which seem to be the most influential parameters on profit. Parameters concerning investments ( $I)$, utilities $\left(P_{E}, P_{W}, E, W\right)$, manure disposal costs $\left(P_{D}\right)$ and frass sales and production $\left(P_{F}, M_{F}, Q_{F}\right)$ seem to have proportionally very little impact on profit in this scenario.

Thus, looking at all these elasticities for all the scenarios together, the model seems to be the most sensitive to the parameters surrounding the production of BSF biomass and its corresponding end product ( $P_{B S F}, M_{B S F}, P_{B S F L}, M_{B S F}, Q_{B S F}$ ), as well as the cost price of starter larvae (PSL). The model also seems to be also fairly sensitive to changes in labour requirements $(L)$ and price of labour $\left(P_{L}\right)$, although less so than the previously mentioned parameters. Depending on the scenario, the model can be somewhat sensitive to the parameters of investments $(I)$ and manure disposal costs $\left(P_{D}\right)$. The model seems to be fairly insensitive to parameters linked to frass ( $\left.P_{F}, M_{F}, Q_{F}\right)$ and very insensitive to utilities parameters $\left(P_{E}, P_{w}, E, W\right)$. 


\subsection{Results Standard scenarios model B}

\subsubsection{High uncertainty scenarios I}

The high uncertainty scenarios assume uncertainty in all parameters that can be changed by the checkboxes in model A. This means that for every parameter where there is a range of values possible, a normal distribution is assumed, instead of a specific parameter value. The minimum value of the parameter is assumed to be 3 standard deviations from the mean, while the maximum value of the parameter is assumed to be 3 standard deviations above the mean. The standard deviation was determined by dividing the absolute difference between the mean and the minimum value by 3 .

Under high uncertainty, several scenarios where run for different margins of the dried larvae (MBSF), frass $\left(M_{F}\right)$ and live larvae $\left(M_{B S F L}\right)$. For these scenarios it was assumed that the margins of dried larvae and frass were the same. So in the scenario of 50\% margins, the frass margin was $50 \%$ and the dried larvae margin was $50 \%$. The same went for the scenarios selling live larvae and frass. So in the $80 \%$ margins scenarios selling live BSF larvae and frass, the margin for live BSF larvae is assumed to be $80 \%$ and the margin for frass is assumed to be $80 \%$.

Running our Monte Carlo inspired calculation tool for these high uncertainty scenarios, it becomes clear that in order for the probability of positive profits to be sufficiently high, the margin needs to be quite high as well. Under this scenario, selling dried larvae at an unrealistic $100 \%$ margin, only results in a positive profit $57 \%$ of the time. However, looking at the IRRs of scenario $f$ with $100 \%$ margins, the IRR is higher than $10 \%$ in $43 \%$ of the renditions (see figure 3.3.1.1). Thus the IRR is likely to be fairly high when the profit is positive. In approximately $43 \%$ of the renditions, the IRR was shown to be higher than $10 \%$. Thus it seems that for high uncertainty the probability for negative profits is between $43-$ $100 \%$ (see table 17), depending on the margins when a farmer sells dried BSF larvae and frass.

Table 17 Results of the Monte Carlo simulations under high uncertainty and sales of dried BSF larvae.

\begin{tabular}{|c|c|c|c|c|c|c|}
\hline $\begin{array}{l}\text { Yearly profits dried BSF } \\
\text { larvae and frass }\end{array}$ & $\begin{array}{l}50 \% \\
\text { margins } \\
\text { (a) }\end{array}$ & $\begin{array}{l}60 \% \\
\text { margins } \\
\text { (b) }\end{array}$ & $\begin{array}{l}70 \% \\
\text { margins } \\
\text { (c) }\end{array}$ & $\begin{array}{l}80 \% \\
\text { margins } \\
\text { (d) }\end{array}$ & $\begin{array}{l}90 \% \\
\text { margins } \\
\text { (e) }\end{array}$ & $\begin{array}{l}100 \% \\
\text { margins } \\
\text { (f) }\end{array}$ \\
\hline$<€ 0$ & $100.00 \%$ & $99.94 \%$ & $99.22 \%$ & $91.28 \%$ & $68.90 \%$ & $42.91 \%$ \\
\hline$€ 0-€ 100,000$ & $0.00 \%$ & $0.06 \%$ & $0.78 \%$ & $8.70 \%$ & $30.80 \%$ & $53.47 \%$ \\
\hline$€ 100,000-€ 200,000$ & $0.00 \%$ & $0.00 \%$ & $0.00 \%$ & $0.02 \%$ & $0.30 \%$ & $3.60 \%$ \\
\hline$€ 200,000-€ 300,000$ & $0.00 \%$ & $0.00 \%$ & $0.00 \%$ & $0.00 \%$ & $0.00 \%$ & $0.02 \%$ \\
\hline$€ 300,000-€ 400,000$ & $0.00 \%$ & $0.00 \%$ & $0.00 \%$ & $0.00 \%$ & $0.00 \%$ & $0.00 \%$ \\
\hline
\end{tabular}

Figure 3.3.1.1 Internal rates of return (IRRs) for scenario I.f: $100 \%$ margins for dried BSF larvae and frass sales.

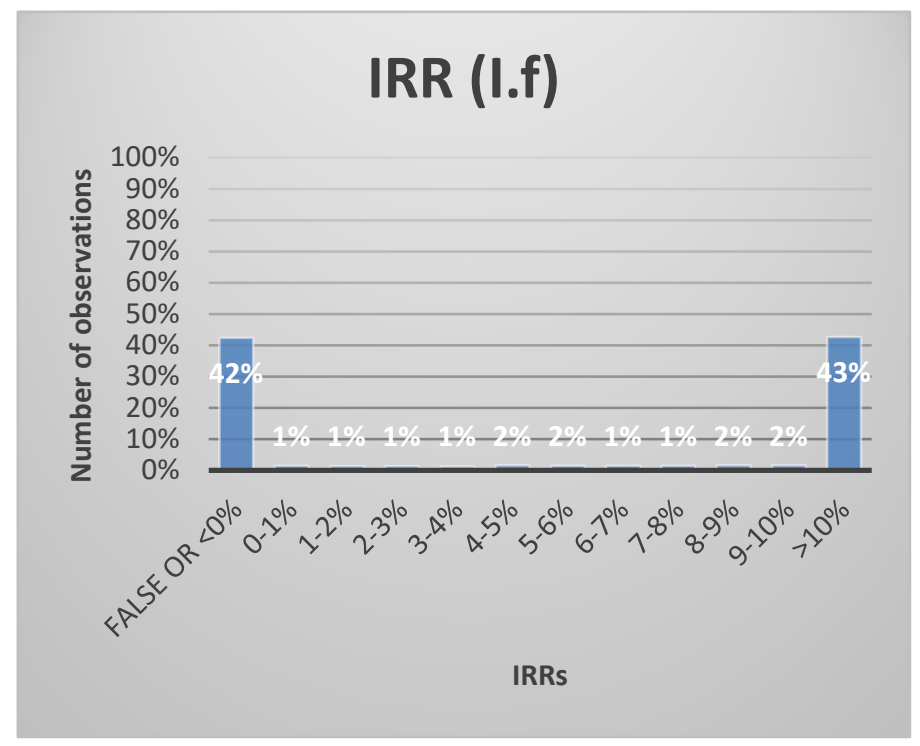


Looking at the results under high uncertainty for a farmer selling live larvae and frass, shows a much more positive picture of potential profits compared to selling dried larvae and frass. Here the probability of negative profits is between 5 and $100 \%$ depending on the margins of the scenarios. Looking at scenario $\mathrm{k}$ with $90 \%$ margins, the probability of a negative profit is only $21 \%$. A closer look at this scenario for the payback period shows that if the profit is positive, the payback period is most likely between 3-4 years (see figure 3.1.1.2). A negative profit returns the value FALSE to the payback period graph, and does the same for payback periods longer than the depreciation period. This shows that for the higher margins, ( $80 \%$ and up), the probability of a positive profit is at least $41 \%$ under high uncertainty.

Table 18 Results of the Monte Carlo simulations under high uncertainty and sales of live BSF larvae.

\begin{tabular}{|c|c|c|c|c|c|c|}
\hline $\begin{array}{l}\text { Yearly profits live BSF } \\
\text { larvae and frass }\end{array}$ & $\begin{array}{l}50 \% \\
\text { margins } \\
(\mathrm{g})\end{array}$ & $\begin{array}{l}60 \% \\
\text { margins } \\
\text { (h) }\end{array}$ & $\begin{array}{l}70 \% \\
\text { margins } \\
\text { (i) }\end{array}$ & $\begin{array}{l}80 \% \\
\text { margins } \\
\text { (j) }\end{array}$ & $\begin{array}{l}90 \% \\
\text { margins } \\
\text { (k) }\end{array}$ & $\begin{array}{l}100 \% \\
\text { margins } \\
\text { (I) }\end{array}$ \\
\hline$<€ 0$ & $100.00 \%$ & $99.87 \%$ & $92.30 \%$ & $59.34 \%$ & $21.21 \%$ & $5.03 \%$ \\
\hline$€ 0-€ 100,000$ & $0.00 \%$ & $0.13 \%$ & $7.70 \%$ & $40.54 \%$ & $75.41 \%$ & $73.67 \%$ \\
\hline$€ 100,000-€ 200,000$ & $0.00 \%$ & $0.00 \%$ & $0.00 \%$ & $0.12 \%$ & $3.38 \%$ & $21.21 \%$ \\
\hline$€ 200,000-€ 300,000$ & $0.00 \%$ & $0.00 \%$ & $0.00 \%$ & $0.00 \%$ & $0.00 \%$ & $0.09 \%$ \\
\hline$€ 300,000-€ 400,000$ & $0.00 \%$ & $0.00 \%$ & $0.00 \%$ & $0.00 \%$ & $0.00 \%$ & $0.00 \%$ \\
\hline
\end{tabular}

Figure 3.3.1.2 Payback periods of scenario I.k: 90\% margins for live BSF larvae and frass sales.

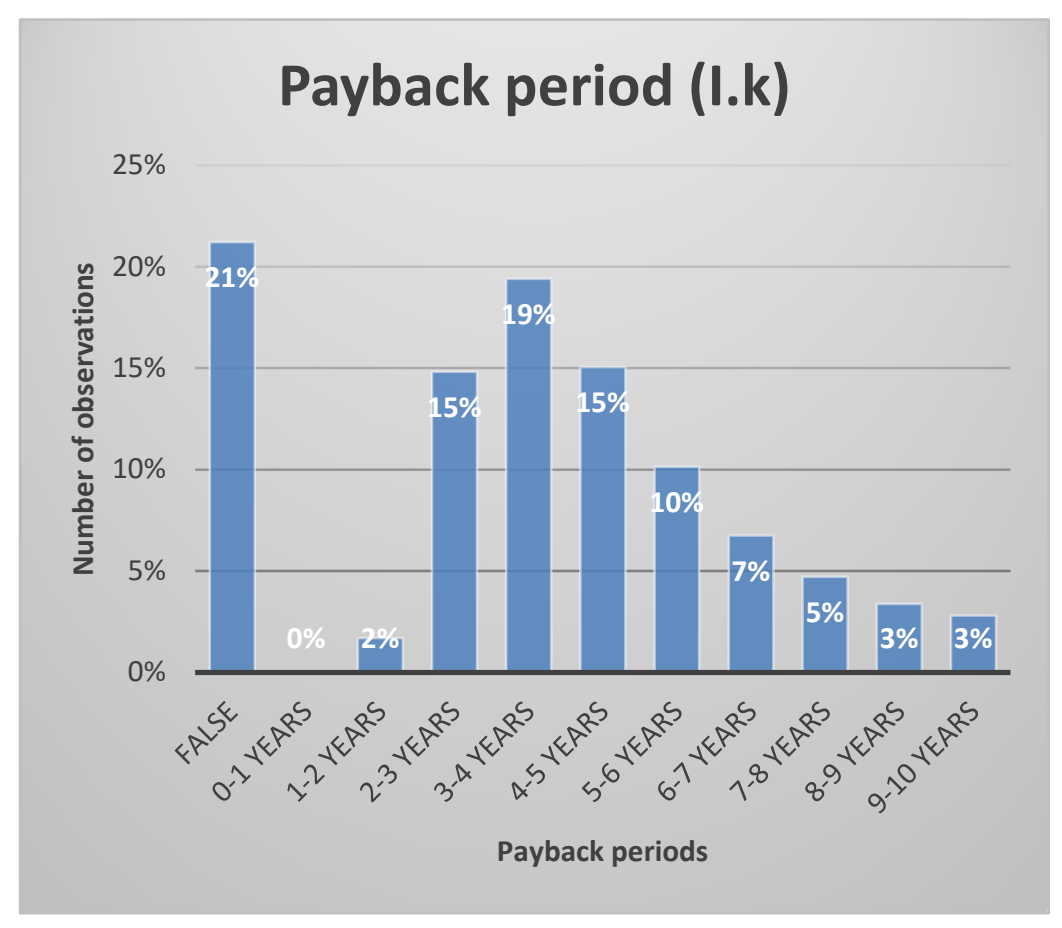

When the payback period is not returned FALSE, due to a negative profit or a payback period longer than 10 years, a payback period between 3 to 4 years is most likely. 


\subsubsection{Medium uncertainty scenarios II}

The medium uncertainty scenario differs from the high uncertainty scenario, due to eliminated uncertainty in the price of frass $\left(\mathrm{P}_{\mathrm{F}}\right)$ and the cost of starter larvae $\left(\mathrm{P}_{\mathrm{SL}}\right)$. $\mathrm{P}_{\mathrm{F}}$ is set at $€ 20$ per tonne, which is comparable to the price of worm compost (Ecocultworms, 2020). This was done because the mean under high uncertainty $(€ 160)$, was deemed quite unrealistic and too far off from the value in our best guess scenario from model A. The price of starter larvae (PSL) is set at $€ 14.29$ per $\mathrm{kg}$ (ACRRES 2021c; van Schelt, 2021, personal communication). This parameter was determined to be very elastic in most of our previously run scenarios for model A. Therefore, the difference between our best guess value from model $A(€ 14.29 / \mathrm{kg})$ and the mean of randomly picked values in model $B(€ 17.14 / \mathrm{kg})$, could lead to vastly different results. Therefore, under the medium uncertainty scenario, the price of starter larvae $(P S L)$ is set at $€ 14.29$ per $\mathrm{kg}$ (ACRRES 2021c, van Schelt, 2021, personal communication).

The results under medium uncertainty immediately show that the probabilities of a positive profit become higher compared to similar margins under high uncertainty. This is probably due to the fixed cost price of starter larvae, since the sensitivity analysis of model A showed the model was very sensitive to this parameter. Comparing selling dried (see table 19) and live larvae scenarios (see table 20), it becomes immediately clear that selling live larvae leads to a higher probability of positive profits under these scenarios. Looking at the scenarios selling dried larvae, only scenario 6 (100\% margins) gives a probability higher than $50 \%$ for a positive profit. The scenarios selling live larvae on the other hand, show this is the case for scenarios with margins higher than $80 \%$ (scenarios 10,11 , and 12). As such, this indicates that selling live larvae is likely to be more profitable compared to selling dried larvae.

Table 19 Results of the Monte Carlo simulations under medium uncertainty and sales of dried BSF larvae.

\begin{tabular}{|c|c|c|c|c|c|c|}
\hline $\begin{array}{l}\text { Yearly profits dried BSF } \\
\text { larvae and frass }\end{array}$ & $\begin{array}{l}50 \% \\
\text { margins } \\
(1)\end{array}$ & $\begin{array}{l}60 \% \\
\text { margins } \\
\text { (2) }\end{array}$ & $\begin{array}{l}70 \% \\
\text { margins } \\
\text { (3) }\end{array}$ & $\begin{array}{l}80 \% \\
\text { margins } \\
(4)\end{array}$ & $\begin{array}{l}90 \% \\
\text { margins } \\
\text { (5) }\end{array}$ & $\begin{array}{l}100 \% \\
\text { margins } \\
(6)\end{array}$ \\
\hline$<€ 0$ & $100.00 \%$ & $99.98 \%$ & $97.59 \%$ & $82.91 \%$ & $57.27 \%$ & $31.35 \%$ \\
\hline$€ 0-€ 100,000$ & $0.00 \%$ & $0.02 \%$ & $2.41 \%$ & $17.08 \%$ & $42.14 \%$ & $63.51 \%$ \\
\hline$€ 100,000-€ 200,000$ & $0.00 \%$ & $0.00 \%$ & $0.00 \%$ & $0.01 \%$ & $0.59 \%$ & $5.14 \%$ \\
\hline$€ 200,000-€ 300,000$ & $0.00 \%$ & $0.00 \%$ & $0.00 \%$ & $0.00 \%$ & $0.00 \%$ & $0.00 \%$ \\
\hline$€ 300,000-€ 400,000$ & $0.00 \%$ & $0.00 \%$ & $0.00 \%$ & $0.00 \%$ & $0.00 \%$ & $0.00 \%$ \\
\hline
\end{tabular}

Table 20 Results of the Monte Carlo simulations under medium uncertainty and sales of live BSF larvae

\begin{tabular}{|c|c|c|c|c|c|c|}
\hline $\begin{array}{l}\text { Yearly profits live BSF } \\
\text { larvae and frass }\end{array}$ & $\begin{array}{l}50 \% \\
\text { margins } \\
(7)\end{array}$ & $\begin{array}{l}60 \% \\
\text { margins } \\
(8)\end{array}$ & $\begin{array}{l}70 \% \\
\text { margins } \\
(9)\end{array}$ & $\begin{array}{l}80 \% \\
\text { margins } \\
(10)\end{array}$ & $\begin{array}{l}90 \% \\
\text { margins } \\
(11)\end{array}$ & $\begin{array}{l}100 \% \\
\text { margins } \\
(12)\end{array}$ \\
\hline$<€ 0$ & $100.00 \%$ & $99.30 \%$ & $82.02 \%$ & $36.76 \%$ & $9.69 \%$ & $1.59 \%$ \\
\hline$€ 0-€ 100,000$ & $0.00 \%$ & $0.70 \%$ & $17.98 \%$ & $63.05 \%$ & $84.74 \%$ & $68.57 \%$ \\
\hline$€ 100,000-€ 200,000$ & $0.00 \%$ & $0.00 \%$ & $0.00 \%$ & $0.19 \%$ & $5.57 \%$ & $29.70 \%$ \\
\hline$€ 200,000-€ 300,000$ & $0.00 \%$ & $0.00 \%$ & $0.00 \%$ & $0.00 \%$ & $0.00 \%$ & $0.14 \%$ \\
\hline$€ 300,000-€ 400,000$ & $0.00 \%$ & $0.00 \%$ & $0.00 \%$ & $0.00 \%$ & $0.00 \%$ & $0.00 \%$ \\
\hline
\end{tabular}




\subsubsection{Low uncertainty scenario III}

Low uncertainty scenarios differ from medium uncertainty scenarios, because uncertainties surrounding initial investments (I) and labour requirements $(\mathrm{L})$ are eliminated. The initial investments (I) are fixed at $€ 193.350$, while the labour requirements (L) are fixed at 2080 hours, approximately 1 FTE based on a 40 hour workweek. This was done because for these parameters, their mean in model B deviated from our best guess scenario of model A. Utilities were not changed because of the extreme inelasticity shown across scenarios in model $A$.

Once again reducing the uncertainty results in a higher probability of a positive profit. For selling dried larvae, the probabilities for positive profits are once again lower compared to similar probabilities when selling live larvae. However, even for dried larvae, when the margins are relatively high, the probabilities for turning negative profits become much lower in this low uncertainty scenario compared to similar higher uncertainty scenarios.

Still, selling live larvae still shows the most promise. Margins that are $70 \%$ or higher have a probability of positive profits higher than $60 \%$.

Table 21 Results of the Monte Carlo simulations under low uncertainty and sales of dried BSF larvae

\begin{tabular}{|c|c|c|c|c|c|c|}
\hline $\begin{array}{l}\text { Yearly profits dried BSF } \\
\text { larvae and frass }\end{array}$ & $\begin{array}{l}50 \% \\
\text { margins } \\
\text { (i) }\end{array}$ & $\begin{array}{l}60 \% \\
\text { margins } \\
\text { (ii) }\end{array}$ & $\begin{array}{l}70 \% \\
\text { margins } \\
\text { (iii) }\end{array}$ & $\begin{array}{l}80 \% \\
\text { margins } \\
\text { (iv) }\end{array}$ & $\begin{array}{l}90 \% \\
\text { margins } \\
\text { (v) }\end{array}$ & $\begin{array}{l}100 \% \\
\text { margins } \\
\text { (vi) }\end{array}$ \\
\hline$<€ 0$ & $99.99 \%$ & $98.67 \%$ & $85.45 \%$ & $54.01 \%$ & $26.66 \%$ & $11.51 \%$ \\
\hline$€ 0-€ 100,000$ & $0.01 \%$ & $1.33 \%$ & $14.55 \%$ & $45.64 \%$ & $69.59 \%$ & $71.38 \%$ \\
\hline$€ 100,000-€ 200,000$ & $0.00 \%$ & $0.00 \%$ & $0.00 \%$ & $0.35 \%$ & $3.75 \%$ & $16.97 \%$ \\
\hline$€ 200,000-€ 300,000$ & $0.00 \%$ & $0.00 \%$ & $0.00 \%$ & $0.00 \%$ & $0.00 \%$ & $0.14 \%$ \\
\hline$€ 300,000-€ 400,000$ & $0.00 \%$ & $0.00 \%$ & $0.00 \%$ & $0.00 \%$ & $0.00 \%$ & $0.00 \%$ \\
\hline
\end{tabular}

Table 22 Results of the Monte Carlo analysis under low uncertainty and sales of live BSF larvae

\begin{tabular}{lllllll} 
Yearly profits live BSF & $50 \%$ & $60 \%$ & $70 \%$ & $80 \%$ & $90 \%$ & $100 \%$ \\
larvae and frass & $\begin{array}{l}\text { margins } \\
(\mathrm{vii})\end{array}$ & $\begin{array}{l}\text { margins } \\
(\mathrm{vifi})\end{array}$ & $\begin{array}{l}\text { margins } \\
\text { (ix) }\end{array}$ & $\begin{array}{l}\text { margins } \\
(\mathrm{x})\end{array}$ & $\begin{array}{l}\text { margins } \\
(\mathrm{xi})\end{array}$ & $\begin{array}{l}\text { margins } \\
(\mathrm{xif})\end{array}$ \\
\hline$<0$ & $99.95 \%$ & $88.87 \%$ & $38.22 \%$ & $7.63 \%$ & $0.97 \%$ & $0.15 \%$ \\
\hline$€ 0-€ 100,000$ & $0.05 \%$ & $11.13 \%$ & $61.74 \%$ & $89.10 \%$ & $73.39 \%$ & $36.43 \%$ \\
\hline$€ 100,000-€ 200,000$ & $0.00 \%$ & $0.00 \%$ & $0.04 \%$ & $3.27 \%$ & $25.59 \%$ & $62.29 \%$ \\
\hline$€ 200,000-€ 300,000$ & $0.00 \%$ & $0.00 \%$ & $0.00 \%$ & $0.00 \%$ & $0.05 \%$ & $1.13 \%$ \\
\hline$€ 300,000-€ 400,000$ & $0.00 \%$ & $0.00 \%$ & $0.00 \%$ & $0.00 \%$ & $0.00 \%$ & $0.00 \%$ \\
\hline
\end{tabular}




\section{Conclusion}

The financial viability and profitability of applying black soldier fly (BSF) larvae to pig manure is not completely cut and dry. There definitely seems to be potential in applying BSF larvae to pig manure, however, specific parameters determine whether this may or may not be financially viable and profitable.

The first thing to notice is that the potential for BSF larvae seems to be higher when the full grown larvae can be sold live. This is mainly due to the low dry matter percentage of BSF larvae. By drying larvae a lot of water and thus weight evaporates. This means that the price of dried larvae needs to be significantly higher than the price for live larvae to make up for this weight loss. In the case of BSF larvae produced on pig manure, the dry matter percentage is $25 \%$. Therefore, the price times margin for dried larvae needs to be at least 4 times as high as the price times margin for live larvae, in order for selling dried larvae to be more profitable. This could be seen both in model A and model B. For our best guess scenario, which assumes a medium level for the price of dried larvae $(€ 12.10)$, only the medium and high price options for live larvae resulted in a higher profit compared to the dried larvae scenario. When looking at Model B, the potential of live larvae becomes even more clear. Model B showed consistently that under all uncertainty levels, the probability of positive profits was higher for live larvae, given similar profit margins. This is not unexpected, since the mean sales price of dried larvae $(€ 12.10)$ was not 4 times higher than the mean sales price of live larvae ( $€ 3.63)$. Furthermore, as indicated by experts in the industry, the margins of dried BSF larvae might be lower than the margins of live larvae, due to significant processing and energy costs in order to produce dried larvae. These dying costs where only indirectly taken into account by the margin (van Schelt, J., 2021 personal communication).

Furthermore, our results show that the price of (dried) larvae, margin of the (dried) larvae, production of larvae and the cost price of starter larvae are important influences on profitability. These parameters were shown to be the most elastic for all scenarios of model A, and thus the most influential parameters with regards to profitability. Our best guess scenario returned a negative result for model $A$. Model $B$ showed for the same margins as our best guess scenario ( $60 \%$ margins) a probability of positive profits of almost zero. However, if the aforementioned key elastic parameters turn out slightly different, our best guess scenario could turn positive profits after all (or result in even more negative profits).

The breakeven point for profit for our best guess scenario was $80 \%$ margin or a cost price of starter larvae of $€ 9.65$ per $\mathrm{kg}$. So, if farmers can set up a business model with a good performance on these parameters, they profit is likely to be positive. For example by directly selling the product to consumers instead of selling through animal shops or by negotiating a better deal for buying starter larvae in large quantities. Another possibility would be to breed their own black soldier fly starter larvae, if the cost price of that venture would remain below $€ 9.65$ per $\mathrm{kg}$ of starter larvae. However, this requires more expertise and knowledge and raises the barriers to entry for pig farmers.

Model B, also showed why high profit margins are important. The higher the uncertainty levels, the more important high profit margins become. For dried BSF larvae the profit margin needs to be at least $90 \%$ if you want a probability of more than 0.5 for positive profits. For live larvae this is at least $70 \%$ margins in the low uncertainty scenario. So if farmers can secure short supply chains close or directly to the consumer and have high margins, producing BSF larvae has the potential to be a profitable venture. This is especially the case, since the IRR is likely to be very high, when profit is positive. Therefore it is important for farmers to explore their sales possibilities beforehand. For example, is there a possibility to sell their live BSF larvae to chicken farmers or replace some of their own (more expensive) feeds? Furthermore, higher sales prices may be warranted when considering arguments that state that BSF larvae provide added value as feedstuff, for example due to positive effects on animal well-being or egg quality. Another avenue to explore is whether or not a lower cost price for starter larvae can be negotiated beforehand with a supplier. However, there is also the possibility, that if BSF larvae are produced on a large scale, a large quantity will be processed and sold as insect meal. Insect meal will have higher labour and energy processing requirements and different prices per $\mathrm{kg}$. These questions can all influence the profitability of producing BSF larvae in a profitable manner. Of course, in order to become profitable, the current restriction of raising BSF larvae on pig manure needs to be lifted. 


\section{Discussion}

Due to the innovative nature of business models involving black soldier fly larvae a lot of the sales information on prices and margins is still difficult to find or closely guarded. Therefore, determination of potential sales prices and margins have to be an educated guess. Besides, it is even more difficult to determine the future trends of these parameters. Perhaps prices will decline when total BSF larvae production reaches a larger scale. In determining the input data for our models it was attempted to lean on conservative estimates instead of painting an extremely rosy picture. The current literature provides a wide range of values, which in some cases seemed unrealistic. For example, literature seems to indicate an extremely high frass value (see figure 5.1 for the conversion of pig manure to frass). In our models we are much more conservative. Our maximum is $€ 300$ per tonne, while literature claims frass could be worth $€ 800$ per tonne. This seems unreasonable looking at comparable invertebrate feces, such as worm compost, which is currently sold at $€ 20$ per tonne. This latter value we used in our best guess scenario as realistic. Decisions had to be made to determine a somewhat conservative, yet realistic depiction of potential values at this moment. Further research into components in the BSF frass that increase its added value, can increase the value of frass at a later stage.
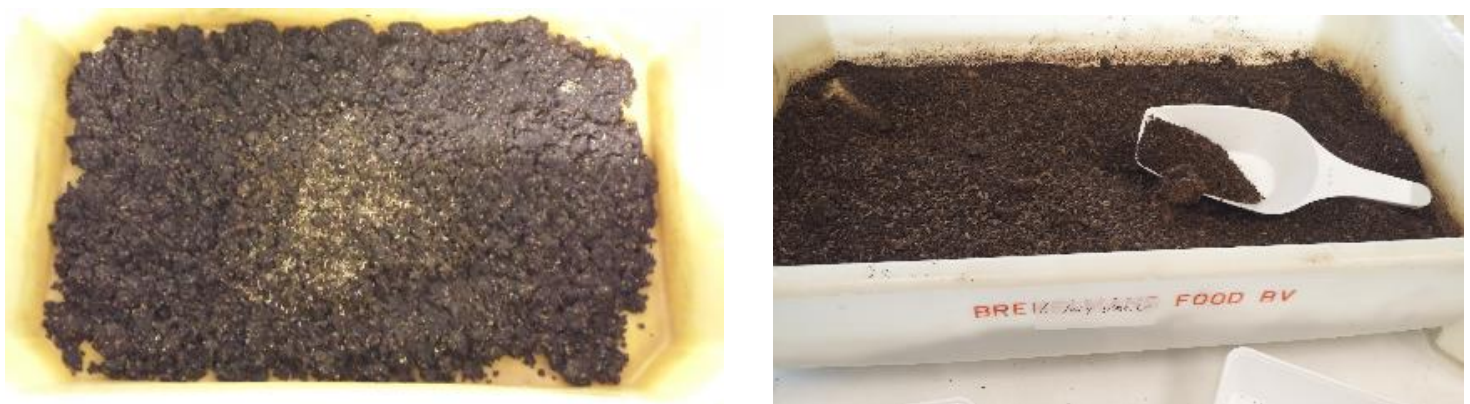

Figure 5.1 Conversion of pig manure (left) to frass (right) (ACRRES, 2021d)

Furthermore, there was no deep dive into the processing and packaging costs or the costs related to sales, due to the limited availability of information for these questions. Instead, this was included in the parameter, called the margin in the model, which uses a percentage approximation from the sales price. Model $A$ uses margins of $60 \%$. More information on the specifics of the processing costs (i.e. drying costs), packaging costs, and sales costs, could lead to a more precise version of the model. Model B focuses mainly on different margins to evaluate what margins would be required in order to have a significant probability of a positive return.

In this analysis, immaterial values and benefits were not taken into account. This means that the importance a farmer attaches to increasing its circularity and sustainability falls outside the models currently presented and were not assigned a monetary value.

From the conclusion it followed that in our current best scenario of model $A$, the profit is expected to be negative, regardless of whether BSF larvae are sold dried or live, given that margins are $60 \%$. However, there are a couple of options that remain unexplored in this model, which could turn this profit positive. As followed from the model, the cost price of starter larvae seems quite important for the profitability of producing BSF larvae. Therefore, either negotiating a lower cost price or breeding own starter larvae has the potential to sufficiently increase profitability. The option of breeding own starter larvae is not explored in the calculation models, since it was assumed adding this step to the production process would form a significant barrier to entry for an individual farmer. Perhaps this assumption could change when determining the profitability of producing own BSF starter larvae on a farmer cooperation level, where multiple farmers cooperate and manage a bigger facility, which process the manure of the surrounding farmers. Bigger facilities for producing BSF larvae and starter larvae as approved animal feeds on organic substrates (GMP+) are currently already up and running in the Netherlands, such as Bestico and Protix.

These results can also be partially extrapolated to other types of waste streams, that are currently legalized for use. BSF larvae have different growth rates depending on the richness (nutritional 
composition) of the waste stream or substrate. More nutritious waste streams will lead to higher growth rates and end weights of BSF larvae and thus a larger production. Other experiments have shown growth of BSF larvae up to $300 \mathrm{mg}$ of wet weight on different experimental times and substrates (Coudron et al., 2018; Gold et al., 2018). Our models showed that parameters surrounding the production of larvae were elastic and had a significant influence on the profitability of BSF larvae production. Production processes do not differ greatly between waste streams. Therefore, BSF larvae production on more nutritious waste streams is likely to be more profitable compared to BSF larvae production on poorer waste streams, such as animal manure. In a similar vein, waste streams that are lower in nutritional value than pig manure are probably less profitable compared to our analysis above. Therefore, another option to increase profitability would be to increase the production of BSF larvae per $\mathrm{kg}$ of waste stream added. Mixing pig manure with another more nutritious waste stream (e.g. catering waste or other food waste), might increase the growth of BSF larvae enough to earn a positive profit. This could possibly also lead to a more efficient use of the manure fraction itself and is worth further evaluating as a new scenario (Zoet, 2021 personal communication).

Although processing pig manure with BSF larvae is not unequivocally profitable, there is definite potential as long as certain conditions are met surrounding starter larvae, production, margins or sales prices. Depending on the specific business model of an individual farmer this venture may or may not be profitable. Further exploration of the profitability of mixing pig manure with different waste streams, and looking at specific business models would therefore be very interesting and would perhaps be able to give a more conclusive answer to the question of profitability of using BSF larvae to process pig manure.

It is currently not legal to process manure or other waste streams combined with manure by applying BSF larvae. As such, BSF larvae produced in this way cannot legally be fed to livestock, pets or aquaculture (IPIFF, 2020). This remains one of the main challenges of applying BSF larvae to animal manure, regardless of profitability potential. Research is being conducted to determine the safety of utilizing BSF larvae raised on animal manure as feed. If this research confirms the potential of BSF larvae to safely process manure, utilizing BSF larvae could be a great step towards increased circularity within agriculture. 
ACRRES, 2019. Internal documentation. sigarendooswormen HERW13032019.xIsx

ACRRES, 2021a. Internal documentation. Berekeningen container geschikt maken wormen of insecten.xlsx

ACRRES, 2021b. Internal documentation. begroting ombouw container tot klimaatcel.xlsx

ACRRES, 2021c. Internal communication about Bestico, April 2, 2021.

ACRRES, 2021d. Internal documentation. Pictures taken by Klaas van Rozen.

ACRRES, n.d.. PPS Biobased Opwaarderen Mest En Digestaat. Retrieved June 16, 2021, from https://www.acrres.nl/projecten_acrres/biobased-opwaarderen-mest-en-digestaat/.

Bortolini, S., L.I. Macavei, J. H. Saadoun, G. Foca, A. Ulrici, F. Bernini, D. Malferrari, L. Setti, D. Ronga and L. Maistrello, 2020. Hermetia illucens (L.) larvae as chicken manure management tool for circular economy. Journal of Cleaner Production 262: 1-10. https://doi.org/10.1016/j.jclepro.2020.121289

Brugge, van S., 2021. Personal communication on electricity use of insect containers, April 9, 2021.

Caruso, D., E. Devic, I.W. Subamia, P. Talamond and E. Baras, 2013. Technical handbook of domestication and production of diptera Black Soldier Fly ( BSF ) Hermetia illucens, Stratiomyidae. PT Penerbit IPB Press, Kencana, Indonesia. 1st ed. (3): 159 pp.

CBS, 2019. Uurloon. Retrieved April 1, 2021, from https://www.cbs.nl/nl-nl/visualisaties/dashboardarbeidsmarkt/ontwikkeling-cao-lonen/uurloon

CBS, 2021. Aardgas en elektriciteit, gemiddelde prijzen van eindverbruikers. Retrieved April 1, 2021, from https://opendata.cbs.nl/statline/?fromstatweb\#/CBS/nl/dataset/81309NED/table

Consumentenbond, 2020. Wat kost een kilowattuur (kWh) elektriciteit? Retrieved April 1, 2021, from https://www.consumentenbond.nl/energie-vergelijken/kwh-prijs

Coudron, C., L. Deleu, M. van Peer, T. Spranghers, E. Delezie, Y. Cornelis and M. van der Borght, 2018. Kweekhandleiding Zwarte soldatenvlieg: Hermetia illucens. 20 pp.

Dortmans B.M.A., S. Diener, B.M. Verstappen and C. Zurbrügg, 2017. Black Soldier Fly Biowaste Processing - A Step-by-Step Guide. Eawag: Swiss Federal Institute of Aquatic Science and Technology, Dübendorf, Switzerland. 1st ed: $100 \mathrm{pp}$.

Ecocultworms, 2020. Wormencompost. Retrieved April 20, 2021, from https://www.ecocultworms.be/wormencompost/

Gollenbeek, L., 2021. Personal communication on key pig figures, April 2, 2021.

IPIFF, 2020. The insect sector milestones towards sustainable food supply chains. IPIFF Secretariat, Brussels, Belgium. 24 pp.

Ites, S., S. Smetana, S. Toepfl and V. Heinz, 2020. Modularity of insect production and processing as a path to efficient and sustainable food waste treatment. Journal of Cleaner Production 248: 117. https://doi.org/10.1016/j.jclepro.2019.119248

Joly, G. and J. Nikiema, 2019. Global experiences on waste processing with black soldier fly (Hermetia illucens): from technology to business. In Resource Recovery and Reuse Series 16. International Water Management Institute (IWMI), Colombo, Sri Lanka. 66 pp. doi: 10.5337/2019.214

Koeijer, T. De, H. Luesink and H. Prins, 2017. Dieraantallen, mestproductie, mestmarkt en kosten mestafzet. Wageningen Economic Research, The Hague, Netherlands. 34 pp. https://doi.org/http://dx.doi.org/10.18174/407574

Kowarschick, W., 2012. Normal Distribution Sigma. Retrieved June 11, 2021, from https://commons.wikimedia.org/wiki/File:Normal_Distribution_Sigma.svg\#filelinks

Liu, T., M. K. Awasthi, H. Chen, Y. Duan, S. K. Awasthi and Z. Zhang, 2019. Performance of black soldier fly larvae (Diptera: Stratiomyidae) for manure composting and production of cleaner compost. Journal of Environmental Management, 251: 1-10. https://doi.org/10.1016/j.jenvman.2019.109593

Maiolo, S., S. Cristiano, F. Gonella and R. Pastres, 2021. Ecological sustainability of aquafeed: An emergy assessment of novel or underexploited ingredients. Journal of Cleaner Production, 294: 1-10. https://doi.org/10.1016/j.jclepro.2021.126266

Miglietta, P. P., F. de Leo, M. Ruberti and S. Massari, 2015. Mealworms for food: A water footprint perspective. Water, 7(11): 6190-6203. https://doi.org/10.3390/w7116190

Newton, L., C. Sheppard, D.W. Watson, G. Burtle, and R. Dove, 2005. Using the black soldier fly, Hermetia illucens, as a value-added tool for the management of swine manure. Journal Korean Entomology and Applied Science, 36(12): 1-17.

Ngwabie, N. M., B. N. Chungong, and F. L. Yengong, 2018. Characterisation of pig manure for methane emission modelling in Sub-Saharan Africa. Biosystems Engineering, 170(1): 31-38. https://doi.org/10.1016/j.biosystemseng.2018.03.009

Niyonsaba, H. H., J. Höhler, J. Kooistra, \& M. P. M. Meuwissen, 2021. Profitability of insect farms. Journal of Insects as Food and Feed, 1-12. https://doi.org/10.3920/JIFF2020.0087

Parodi, A., I. J. M. De Boer, W. J. J. Gerrits, J. J. A. van Loon, M. J. W. Heetkamp, J. van Schelt, J. E. Bolhuis and H. H. E. van Zanten, 2020. Bioconversion efficiencies, greenhouse gas and ammonia emissions during black soldier fly rearing - A mass balance approach. Journal of Cleaner Production, 271: 1-9. https://doi.org/10.1016/j.jclepro.2020.122488

Pleissner, D., and S. Smetana, 2020. Estimation of the economy of heterotrophic microalgae- and 
insect-based food waste utilization processes_supplementary information. Waste Management, 102: 198-203.

Protix., n.d.. OERei: Natural feed for chickens, a better tasting egg. Retrieved June 10, 2021, from https://protix.eu/products_by_protix/\#oerei

Rijksoverheid, 2016. Nederland circulair in 2050. In Rijksbreed programma Circulaire Economie. 72 pp.

Roffeis, M., J. Almeida, M.E. Wakefield, T. R. A. Valada, E. Devic, N. Koné, M. Kenis, S. Nacambo, E. C. Fitches, G. K. D. Koko, E. Mathijs, W. M. J. Achten and B. Muys, 2017. Life cycle inventory analysis of prospective insect based feed production in West Africa. Sustainability (Switzerland), 9(10): 1-27. https://doi.org/10.3390/su9101697

Rozen, K. van, 2021. Personal communication about batch experiments with pig manure, April 2, 2021

Rustad, I. H., 2016. Life cycle assessment of fish feed produced from the black soldier fly (Hermetia illucens) (Master Thesis). Norwegian University of Science and Technology, Trondheim, Norway. $53 \mathrm{pp}$.

Schelt, J. van. 2021. Personal communication on the drying process, August 27, 2021

Spranghers, T., Michiels, J., Vrancx, J., Ovyn, A., Eeckhout, M., de Clercq, P., de Smet, S, 2017. Gut antimicrobial effects and nutritional value of black soldier fly (Hermetia illucens L.) prepupae for weaned piglets. Animal Feed Science and Technology. https://doi.org/10.1016/j.anifeedsci.2017.08.012

Smetana, S., E. Schmitt and A. Mathys, 2019. Sustainable use of Hermetia illucens insect biomass for feed and food: Attributional and consequential life cycle assessment. Resources, Conservation and Recycling, 144: 285-296. https://doi.org/10.1016/j.resconrec.2019.01.042

Verbeke, W., T. Spranghers, P. de Clercq, S. de Smet, B. Sas and M. Eeckhout, 2015. Insects in animal feed: Acceptance and its determinants among farmers, agriculture sector stakeholders and citizens. Animal Feed Science and Technology, 204: 72-87. https://doi.org/10.1016/j.anifeedsci.2015.04.001

Visgigant.nl., 2021. Maden 1 liter. Retrieved April 6, 2021, from https://www.visgigant.nl/maden-1liter

Voervoorvis.nl., 2021. Larve Zwarte Soldaatvlieg (Groot) (10 Liter). Retrieved April 6, 2021, from https://www.voervoorvis.nl/larve-zwarte-soldaatvlieg-groot-10-liter/

Waternet., 2021. Wat kost een kuub water? Retrieved April 18, 2021, from https://www.waternet.nl/veelgestelde-vragen/drinkwater/wat-kost-kuub-water/

Zoet, L. 2021. Personal communication on discussion section, August 27, 2021 


\section{Appendix 1 Overview of parameters in the dashboard of model $A$}

Most parameters have three levels to choose from in the dashboard: a low, medium and high option. If a parameter has multiple levels to choose from in the dashboard, one can choose by checking the corresponding box in the checkbox. The parameters in model $A$ that can be adjusted by the checkboxes are:

- $\quad$ Production of BSF larvae (Q $\left.Q_{B S F}\right)$ : Influences the parameter level chosen for "Production of fresh larvae per tonne of dry pig manure (in $\mathrm{kg}$ )"

- $\quad$ Sales price of dried BSF larvae $\left(P_{B S F}\right)$ : Influences the parameter level chosen for "Sales price per $\mathrm{kg}$ of dried larvae $\left(P_{B S F}\right)$ ".

- $\quad$ Production of BSF frass $\left(Q_{E}\right)$ : Influences the parameter level chosen for "Production of dried BSF frass fertilizer (DM) per tonne of dry pig manure (in $\mathrm{kg}$ )".

- $\quad$ Sales Price of BSF frass $\left(P_{F}\right)$ : Influences the parameter level chosen for "Sales price per tonne of BSF frass $\left(P_{F}\right)^{\prime \prime}$.

- $\quad$ Labour requirements ( $L$ ): Influences the parameter level chosen for "Total Yearly labour hours (L)".

- $\quad$ Sales price of live larvae $\left(P_{B S F L}\right)$ : Influences the parameter level chosen for "Sales price per kg of live larvae $\left(P_{B S F L}\right)$ ". This parameter only has an influence when it is indicated that some of the BSF biomass produced is sold alive.

- $\quad$ Disposal costs for manure $\left(P_{D}\right)$ : Influences the parameter level chosen for "Disposal costs per tonne of pig manure $\left(P_{D}\right)^{\prime \prime}$.

- $\quad$ Cost price of starter larvae $\left(P_{S L}\right)$ : Influences the parameter level chosen for "Cost price per $\mathrm{kg}$ of starter larvae $\left(P_{S L}\right)^{\prime \prime}$.

- Electricity requirements (E): Influences the parameter level chosen for "Yearly electricity requirements per container".

- $\quad$ Water requirements $(W)$ : Influences the parameter level chosen for "Yearly water requirements $(\mathrm{W})^{\prime \prime}$.

Other parameters can be changed in the dashboard of the Excel calculation model. These parameters include inputs regarding the company details, such as the number of pigs held by a farmer and the percentage of pig manure that a farmer wants to process with BSF larvae. Other parameters regard the venture details such as the timeframe of the insect cycle and expected cycle capacity per container. Other relevant parameters that can be changed directly in the dashboard are the parameters related to company costs: Price per kwh, price per $\mathrm{m}^{3}$ of water and price per labour hour. The final adjustable parameters can be found below the business model details. Here one can adjust two discount rates to calculate two different NPVs and most importantly, change the parameters linked to margins of each of the outputs. One can change the margin of the dried BSF larvae, the margin of the BSF frass and the margin of live full grown BSF larvae. These margins indicate the difference in final sales price and the revenue the farmer gets for his product minus variable processing, marketing and logistics costs. 


\section{Appendix 2 Definition of key financial numbers and metrics}

Break-even point: A break-even point is a situation in which a venture's yearly revenues and costs are equal. Thus, resulting in a net profit of zero.

Discount rate: The discount rate is the rate of return used to discount future cashflows back to their present values. This rate can also be seen as the required rate of return, and indicates the minimum rate of return an investor requires.

Internal rate of return (IRR): The internal rate of return represents the discount rate at which the NPV is 0 . Thus, it represents the potential annual rate of return of the investment.

Net present value (NPV): Net present value is the value of all future cashflows of an investment discounted by a given discount rate to the present value. The discount rate represents the required return on investment by the investor. An investment with a negative NPV should be avoided. In the calculation model there is the possibility to calculate the NPVs of two possible discount rates. Standard the low discount rate is set at $3 \%$, the high discount rate is set at $7 \%$.

Payback period $(P P)$ : The payback period indicates the time it takes in order for an investment to be recovered, until the investment has reached the break-even-point.

$P P=$ Initial investments/Yearly cashflows.

Yearly Cashflows: Cashflows are the difference between cash (and cash-equivalents) inflows and outflows resulting from a business activity. Indirect costs, such as depreciation costs, that do not have actual outflows are not considered a cash outflow.

Yearly Cashflows = Yearly Profits + Yearly depreciation costs

Yearly Costs: direct costs required in order to produce the outputs, as well as indirect costs. Indirect costs of the investment are represented by the depreciation costs.

Yearly Costs $=$ Starter larvae costs + labour costs + utilities costs + depreciation costs.

Yearly Profits: The difference between yearly revenues received and yearly costs of inputs used.

Yearly Profits $=$ Yearly Revenues - Yearly Costs

Yearly Revenues: Income generated from business operations

Yearly Revenues $=$ BSF frass revenues + BSF dried larvae revenues + Reduction of manure disposal costs. 


\section{Appendix 3 Input values for model $A$}

Table 23 Depreciation period, discount rate, and margin values for model $A$

\begin{tabular}{ll} 
Business model details & \\
\hline Depreciation period (in years) & 10 years \\
\hline Discount rate (low) & $3 \%$ \\
\hline Discount rate (high) & $7 \%$ \\
\hline Margin of final sales price dried larvae to farmer (MSF) & $60 \%$ \\
\hline Margin of final sales price of BSF frass fertilizer to farmer (MF) & $60 \%$ \\
\hline Margin of final sales price alive larvae to farmer(MBSL) & $60 \%$ \\
\hline
\end{tabular}

Table 24 Utility and labour cost values for model $A$

\begin{tabular}{llrl} 
Utilities costs and labour cost & & & \\
Price per $k W h\left(P_{E}\right)$ & $€$ & 0.07 (CBS, 2021) \\
\hline Price per m3 of water $\left(P_{W}\right)$ & $€$ & 0.83 (Waternet, 2021) \\
\hline Price per labour hour $\left(P_{L}\right)$ & $€$ & 22.19 (CBS, 2019)
\end{tabular}

Table 25 Range of values for different parameters in model $A$

\begin{tabular}{|c|c|c|c|c|c|}
\hline Other values & Minimum value & Medium value & Maximum value & $\begin{array}{l}\text { Best guess } \\
\text { scenario } \\
\text { value }\end{array}$ & \\
\hline $\begin{array}{l}\text { Sales price of dried larvae per } \mathrm{kg} \\
\left(P_{B S F}\right)\end{array}$ & $€ 6.50$ & $€ 12.10$ & $€ 17.70$ & $€ 12.10$ & $\begin{array}{l}\text { (Ites et al., 2020; } \\
\text { Voervoorvis.nl, 2021) }\end{array}$ \\
\hline $\begin{array}{l}\text { Sales price of live larvae per } \mathrm{kg} \\
\left(P_{B S F L}\right)\end{array}$ & $€ 2.50$ & $€ 3.63$ & $€ 4.75$ & $€ 3.63$ & $\begin{array}{l}\text { (Niyonsaba et al., 2021; } \\
\text { Visgigant.nl, 2021) }\end{array}$ \\
\hline $\begin{array}{l}\text { Sales price of BSF frass per } \\
\text { tonne }\left(P_{F}\right)\end{array}$ & $€ 20$ & $€ 160$ & $€ 300$ & $\underline{€ 20}$ & $\begin{array}{l}\text { (Ecocultworms, 2020; } \\
\text { Rustad, 2016) }\end{array}$ \\
\hline $\begin{array}{l}\text { Cost price of starter larvae per } \\
k g\left(P_{S L}\right)\end{array}$ & $€ 14.29$ & $€ 17.14$ & $€ 20$ & $€ 14.29$ & $\begin{array}{l}\text { ((ACRRES 2021C, Internal } \\
\text { communication; Pleissner \& } \\
\text { Smetana, 2020) }\end{array}$ \\
\hline $\begin{array}{l}\text { Disposal costs per tonne of pig } \\
\text { manure }\left(P_{D}\right)\end{array}$ & $€ 18.00$ & $€ 20.00$ & $€ 22.00$ & $€ 20.00$ & $\begin{array}{l}\text { (Gollenbeek, L., 2021, } \\
\text { personal correspondence). }\end{array}$ \\
\hline Total Yearly labour hours (L) & 2080 hours & 3120 hours & 4160 hours & 2080 hours & $\begin{array}{l}\text { (Dortmans et al., 2017; Ites } \\
\text { et al., 2020; Joly \& } \\
\text { Nikiema, 2019; Maiolo et } \\
\text { al., 2021; Roffeis et al., } \\
\text { 2017) }\end{array}$ \\
\hline $\begin{array}{l}\text { Production of fresh larvae per } \\
\text { tonne of dry pig manure (in } \mathrm{kg} \text { ) } \\
\left(q_{B S F L}\right)\end{array}$ & $329 \mathrm{~kg} /$ tonne & $358 \mathrm{~kg} /$ tonne & $386 \mathrm{~kg} /$ tonne & $\underline{358 \mathrm{~kg} / \text { tonne }}$ & $\begin{array}{l}\text { (Newton et al., 2005; } \\
\text { Rozen, K. van, Personal } \\
\text { correspondence, April 2021) }\end{array}$ \\
\hline $\begin{array}{l}\text { Production of dried BSF frass } \\
\text { fertilizer (DM) per tonne of dry } \\
\text { pig manure (in } \mathrm{kg})\left(q_{f}\right)\end{array}$ & $614 \mathrm{~kg} /$ tonne & $622 \mathrm{~kg} /$ tonne & $630 \mathrm{~kg} /$ tonne & $\underline{622 \mathrm{~kg} / \text { tonne }}$ & $\begin{array}{l}\text { (Newton et al., 2005; } \\
\text { Rozen, K. van, Personal } \\
\text { correspondence, April 2021) }\end{array}$ \\
\hline $\begin{array}{l}\text { Yearly electricity requirements } \\
\text { per container }(e)\end{array}$ & $10,000 \mathrm{kwh}$ & $11,500 \mathrm{kwh}$ & $13,000 \mathrm{kwh}$ & $\underline{10,000 \mathrm{kwh}}$ & $\begin{array}{l}\text { (Brugge, van S., Personal } \\
\text { correspondence, April 2021) }\end{array}$ \\
\hline Yearly water requirements (W) & $246 \mathrm{~m} 3$ & $3,308 \mathrm{~m} 3$ & $6,371 \mathrm{~m} 3$ & $\underline{6,371 \mathrm{~m} 3}$ & $\begin{array}{l}\text { (Miglietta et al., 2015; } \\
\text { Pleissner \& Smetana, 2020) }\end{array}$ \\
\hline
\end{tabular}




\section{Appendix 4 Additional tables and figures model $A$}

\section{Best guess scenario $(A)$}

Table 26 Yearly revenues split out for best guess scenario (A)

\begin{tabular}{lccc} 
Revenues split out (A) & $€$ & 175,869 \\
Revenue dried BSF larvae biomass & $€$ & 2,020 \\
\hline Revenue BSF frass & $€$ & 18,047 \\
\hline Reduction in disposal costs & $€$ & -
\end{tabular}

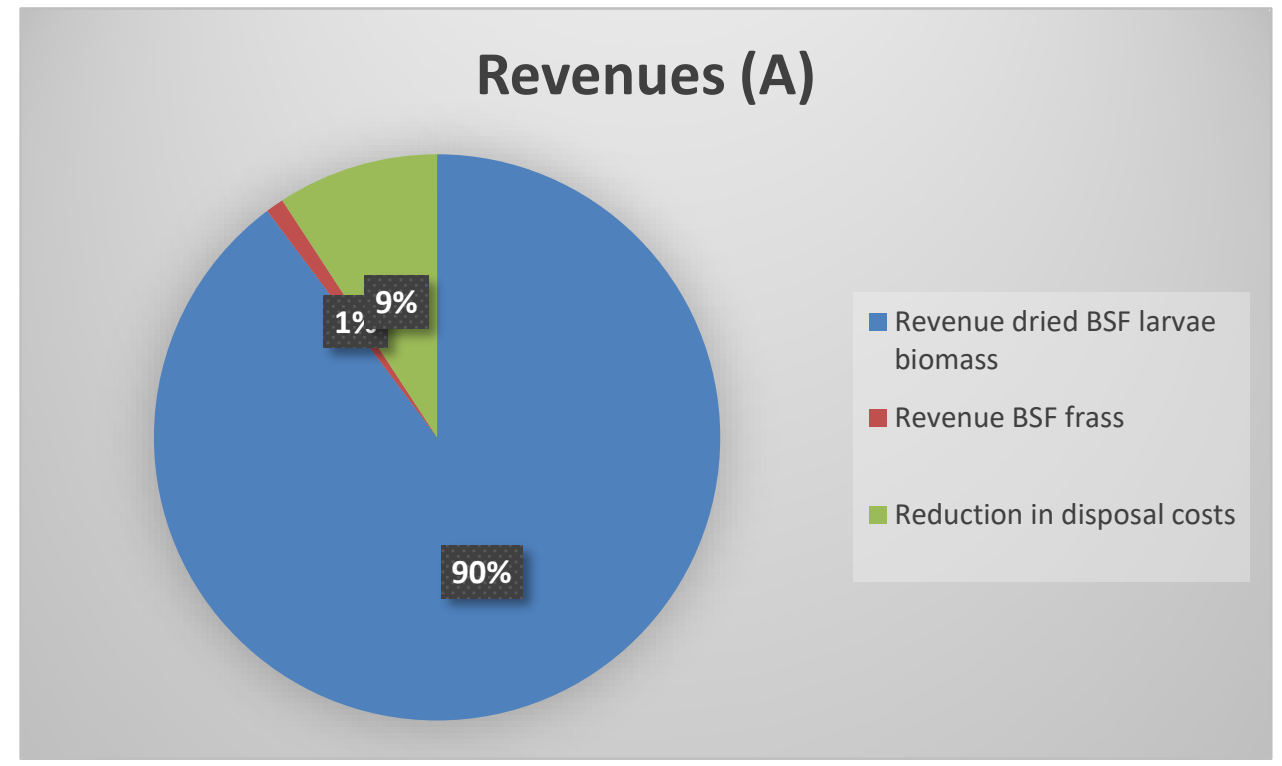

Figure A.1 Revenues for best guess scenario A

Table 27 Yearly costs split out for best guess scenario A

\begin{tabular}{llr} 
Costs split out $(\mathbf{A})$ & $€$ & 182,015 \\
Starter larvae costs & $€$ & 19,335 \\
\hline Depreciation costs & $€$ & 46,155 \\
\hline Yearly labour costs & $€$ & 7,388
\end{tabular}




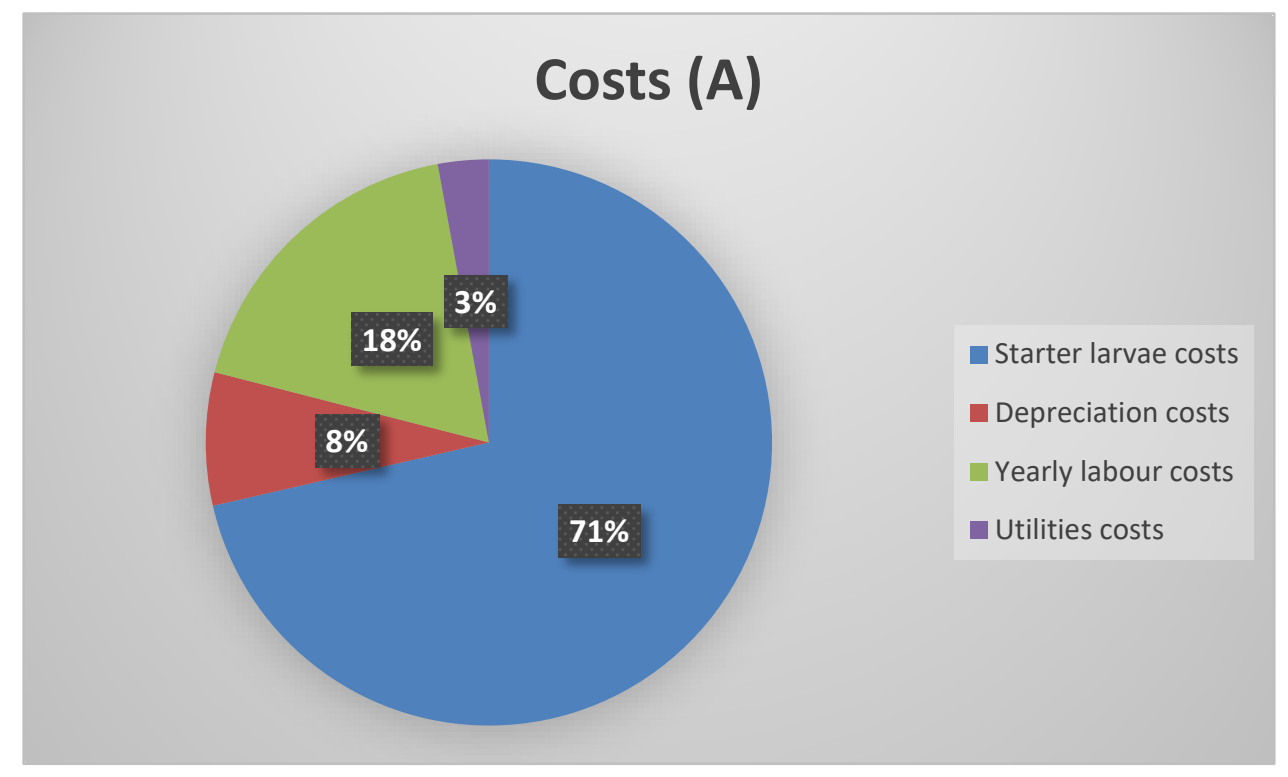

Figure A. 2 Costs for best guess scenario A

Table 28 Other key figures for best guess scenario $A$

\begin{tabular}{lc} 
Other key figures (A) & $270,702 \mathrm{~kg} / \mathrm{year}$ \\
\hline Amount of dry matter pig manure processed & 3 containers \\
\hline Number of insect containers (Rounded up) & 2.25 containers \\
\hline Number of insect containers (Not Rouded up) & $12,741 \mathrm{~kg} / \mathrm{year}$ \\
\hline Starter larvae required & $168,318 \mathrm{~kg} / \mathrm{year}$ \\
\hline Yearly BSF dry matter frass produced (QF) & $96,897 \mathrm{~kg} / \mathrm{year}$ \\
\hline Yearly fresh BSF larvae produced (total) (QT) & $-\mathrm{kg} / \mathrm{year}$ \\
\hline Yearly fresh BSF larvae produced (for Sale) (QBSF) & $24,224 \mathrm{~kg} / \mathrm{year}$ \\
\hline Yearly dried BSF larvae produced (QBSF) & $30,000 \mathrm{kwh} / \mathrm{year}$ \\
\hline Electricity used to heat the containers (E) & $6371 \mathrm{~m} 3 / \mathrm{year}$
\end{tabular}

\section{Best guess live scenario (B)}

Table 29 Yearly revenues split out for best guess live scenario (B)

\begin{tabular}{llr} 
Revenues split out (B) & $€$ & - \\
Revenue dried BSF larvae biomass & $€$ & 2,020 \\
\hline Revenue BSF frass & $€$ & 18,047 \\
\hline Reduction in disposal costs & $€$ & 210,812 \\
\hline Revenue live BSF larvae biomass & & \\
\hline
\end{tabular}




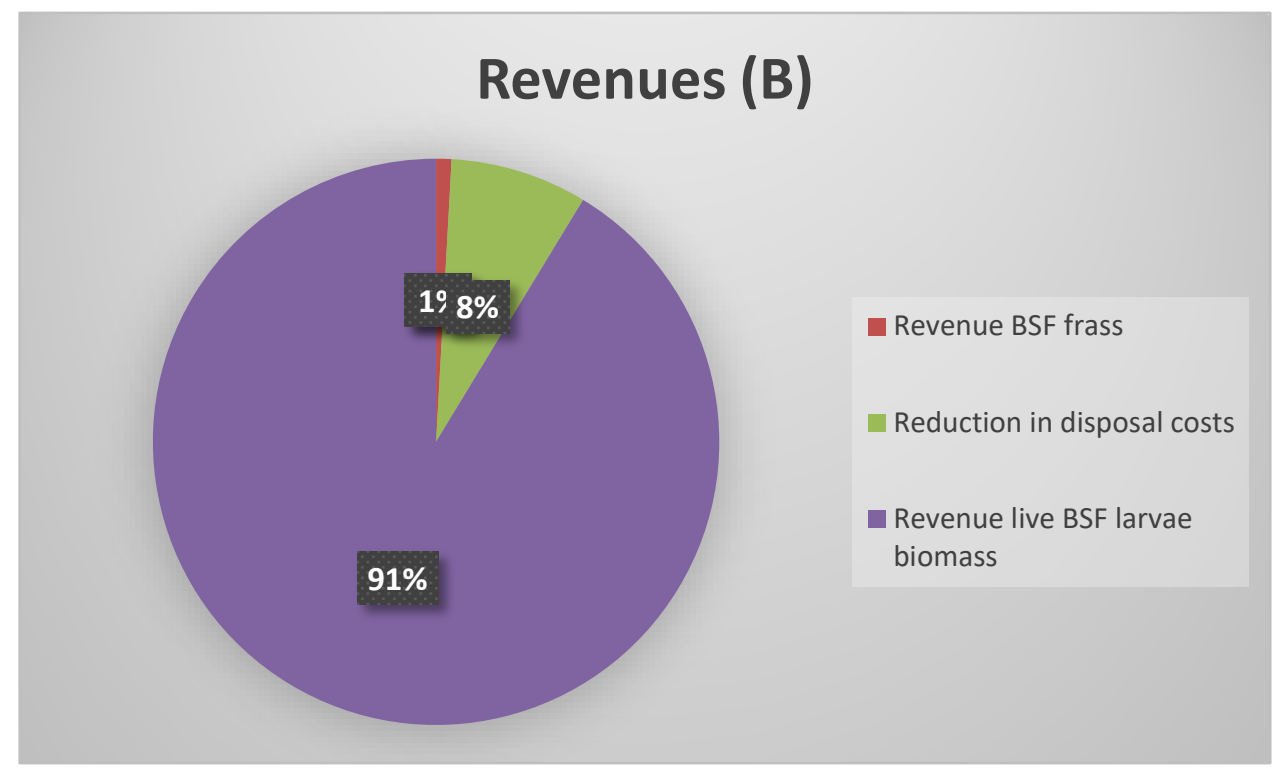

Figure B.1 Revenues for best guess live scenario $B$

Table 30 Yearly costs split out for best guess live scenario B

\begin{tabular}{lcc} 
Costs split out & $€$ & 182,015 \\
Starter larvae costs & $€$ & 19,335 \\
\hline Depreciation costs & $€$ & 46,155 \\
\hline Yearly labour costs & $€$ & 7,388
\end{tabular}

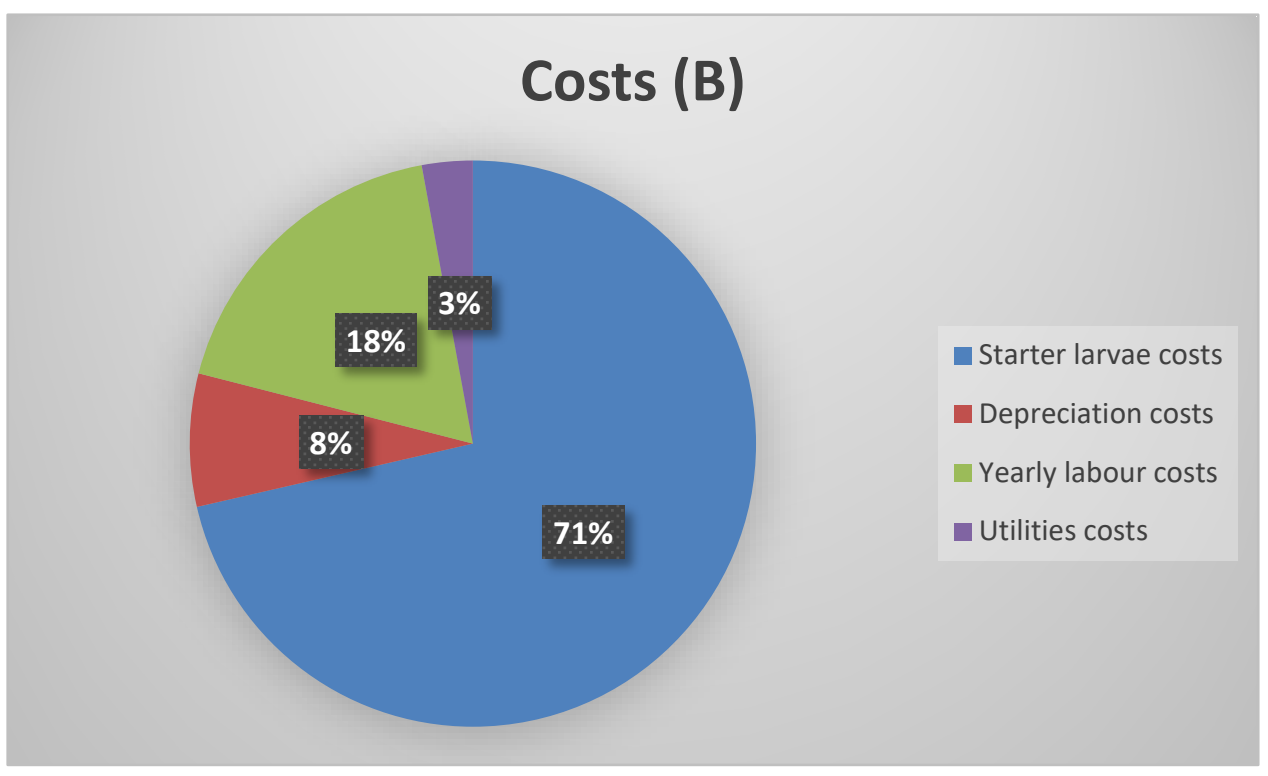

Figure B.2 Costs for best guess live scenario $B$ 
Table 31 Other key figures for best guess live scenario $B$

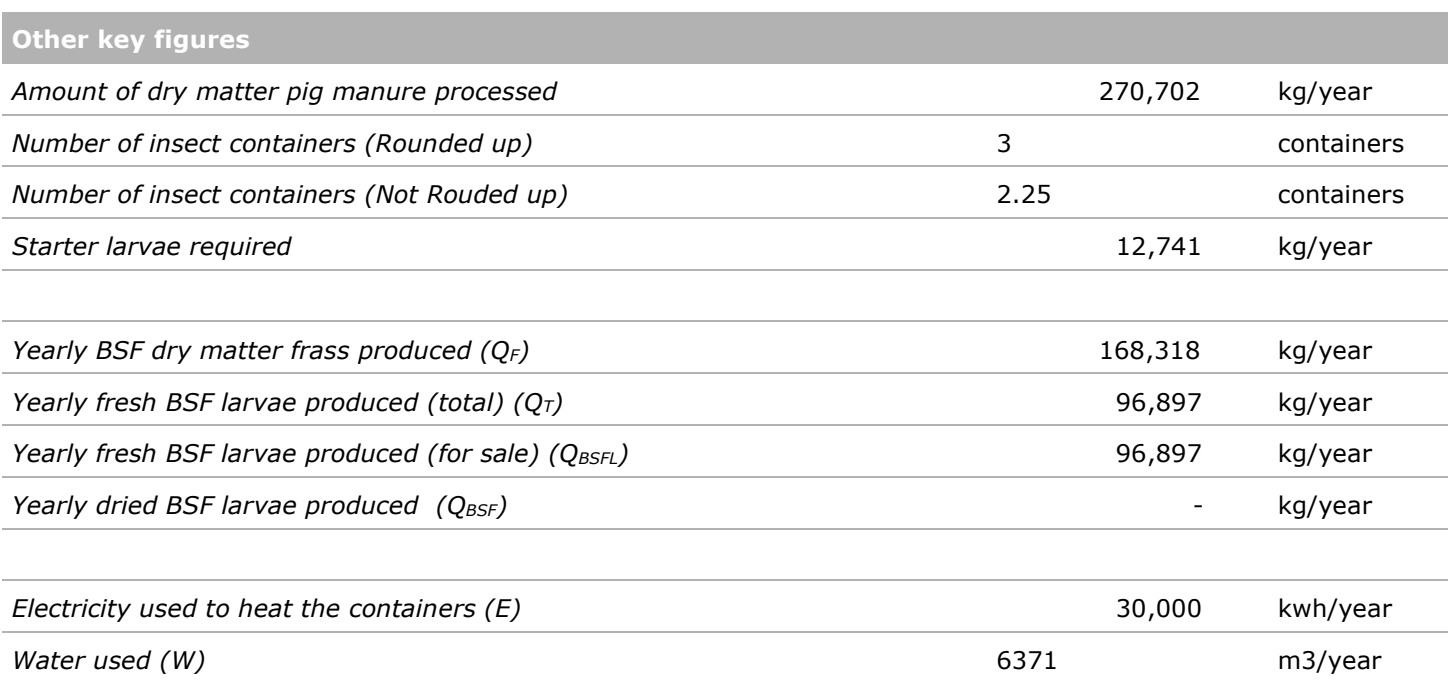

\section{Medium scenario (C)}

Table 32 Yearly revenues split out for medium scenario C

\begin{tabular}{llc} 
Revenues split out (C) & & 175,869 \\
\hline Revenue dried BSF larvae biomass & $€$ & 16,159 \\
\hline Revenue BSF frass & $€$ & 18,047 \\
\hline Reduction in disposal costs & $€$ & -
\end{tabular}

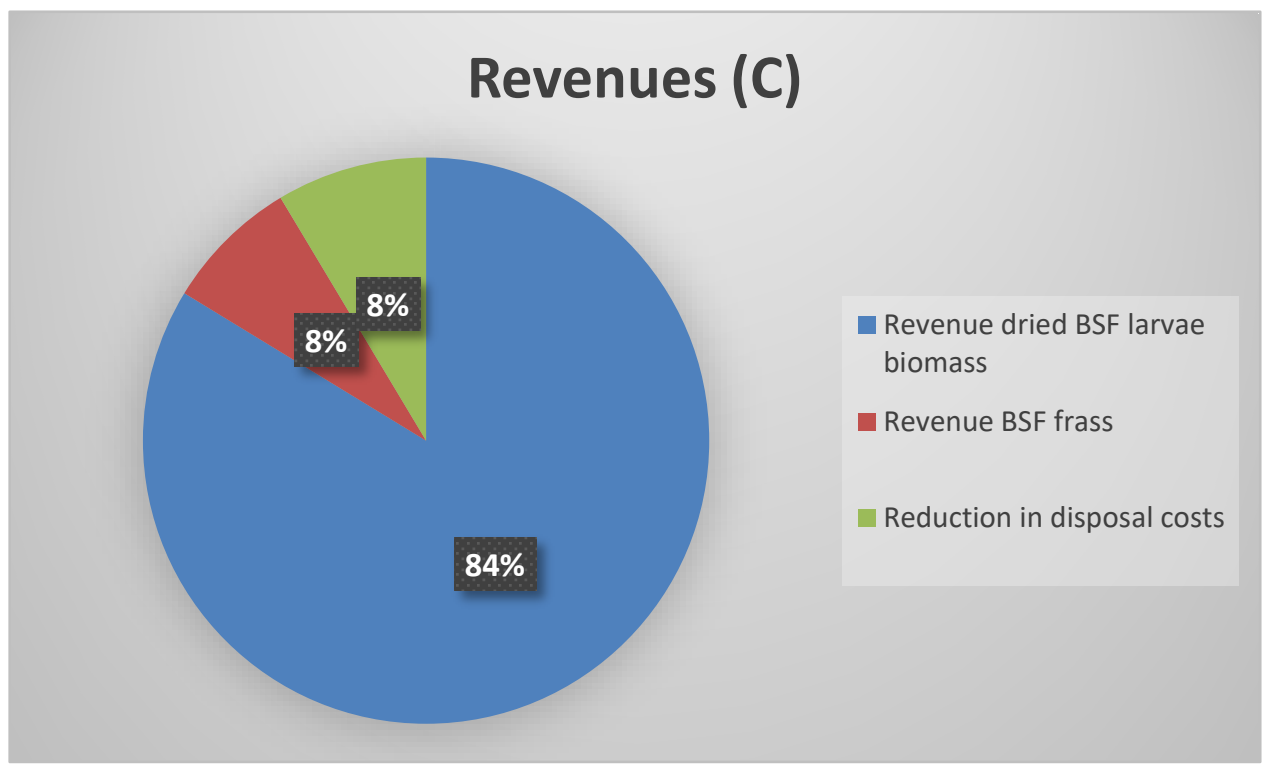

Figure C.1 Revenues for medium scenario C 
Table 33 Yearly costs split out for medium scenario C

\begin{tabular}{lcc} 
Costs split out (C) & & \\
Starter larvae costs & $€$ & 218,418 \\
\hline Depreciation costs & $€$ & 28,989 \\
\hline Yearly labour costs & $€$ & 69,233 \\
\hline Utilities costs & $€$ & 5,161 \\
\hline
\end{tabular}

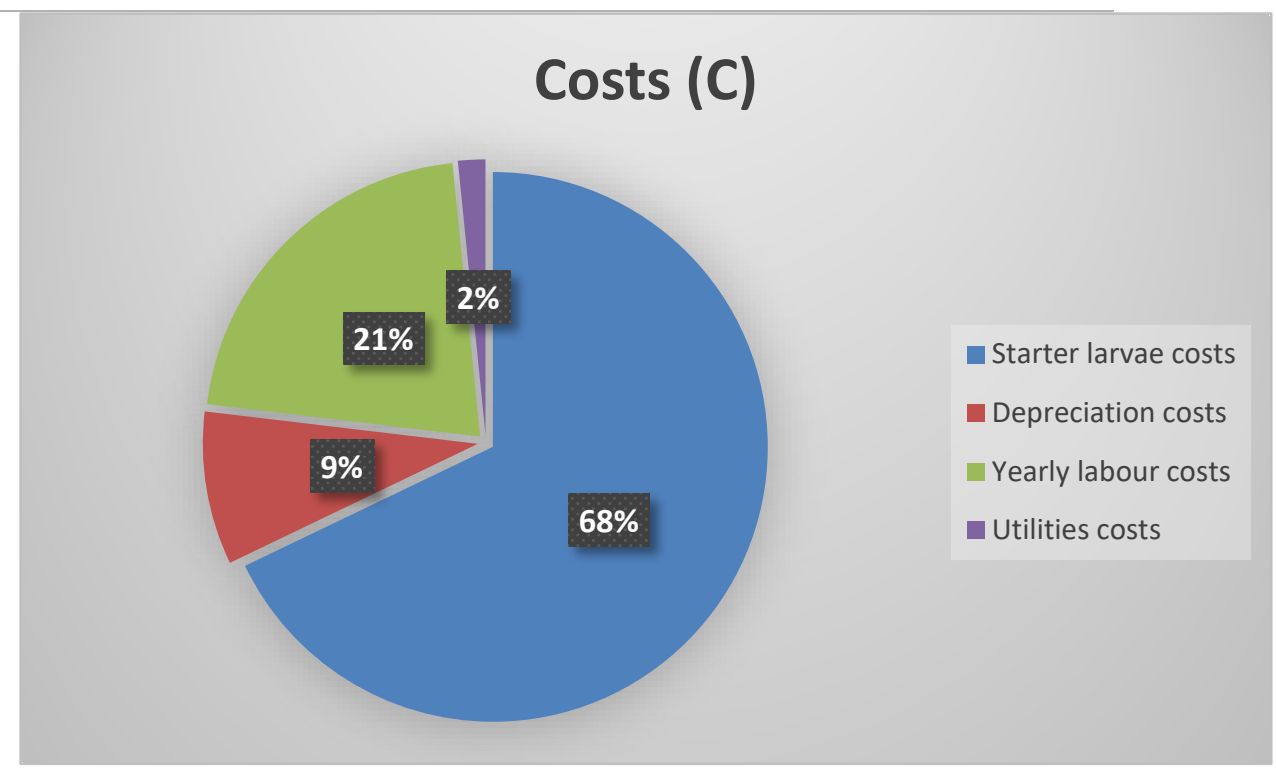

Figure C. 2 Costs for medium scenario C

Table 34 Other key figures for medium scenario C

\begin{tabular}{|c|c|}
\hline Other key figures (C) & \\
\hline Amount of dry matter pig manure processed & $270,702 \mathrm{~kg} /$ year \\
\hline Number of insect containers (Rounded up) & 3 containers \\
\hline Number of insect containers (Not Rounded up) & 2.25 containers \\
\hline Starter larvae required & $12,741 \mathrm{~kg} /$ year \\
\hline Yearly BSF dry matter frass produced $\left(Q_{F}\right)$ & $168,318 \mathrm{~kg} /$ year \\
\hline Yearly fresh BSF larvae produced (total) $\left(Q_{T}\right)$ & $96,897 \mathrm{~kg} /$ year \\
\hline Yearly fresh BSF larvae produced (for sale) ( $Q_{B S F L}$ ) & - kg/year \\
\hline Yearly dried BSF larvae produced ( $Q_{B S F}$ ) & $24,224 \mathrm{~kg} /$ year \\
\hline Electricity used to heat the containers (E) & $34,500 \mathrm{kwh} / \mathrm{year}$ \\
\hline Water used (W) & 3308 m3/year \\
\hline
\end{tabular}




\section{Most favourable scenario (D)}

Table 35 Yearly revenues split out for most favourable scenario $D$

\begin{tabular}{|c|c|c|}
\hline \multicolumn{3}{|l|}{ Revenues split out (D) } \\
\hline Revenue dried BSF larvae biomass & $€$ & 277,733 \\
\hline Revenue BSF frass & $€$ & 30,698 \\
\hline Reduction in disposal costs & $€$ & 19,851 \\
\hline Revenue live BSF larvae biomass & $€$ & - \\
\hline
\end{tabular}

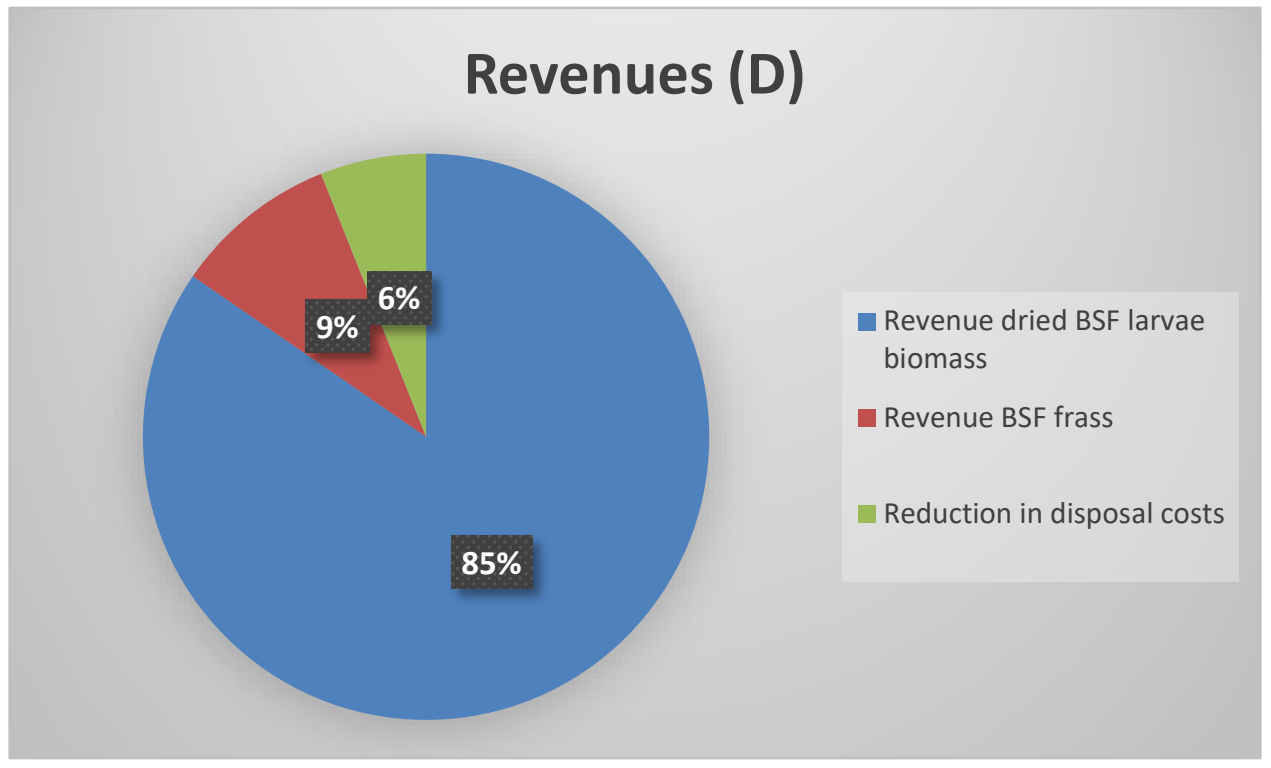

Figure D.1 Revenues for most favourable scenario $D$

Table 36 Costs split out for most favourable scenario $D$

\begin{tabular}{llc} 
Costs split out (D) & & \\
Starter larvae costs & $€$ & 182,015 \\
\hline Depreciation costs & $€$ & 19,963 \\
\hline Yearly labour costs & $€$ & 46,155 \\
\hline Utilities costs & $€$ & 2,320 \\
\hline
\end{tabular}

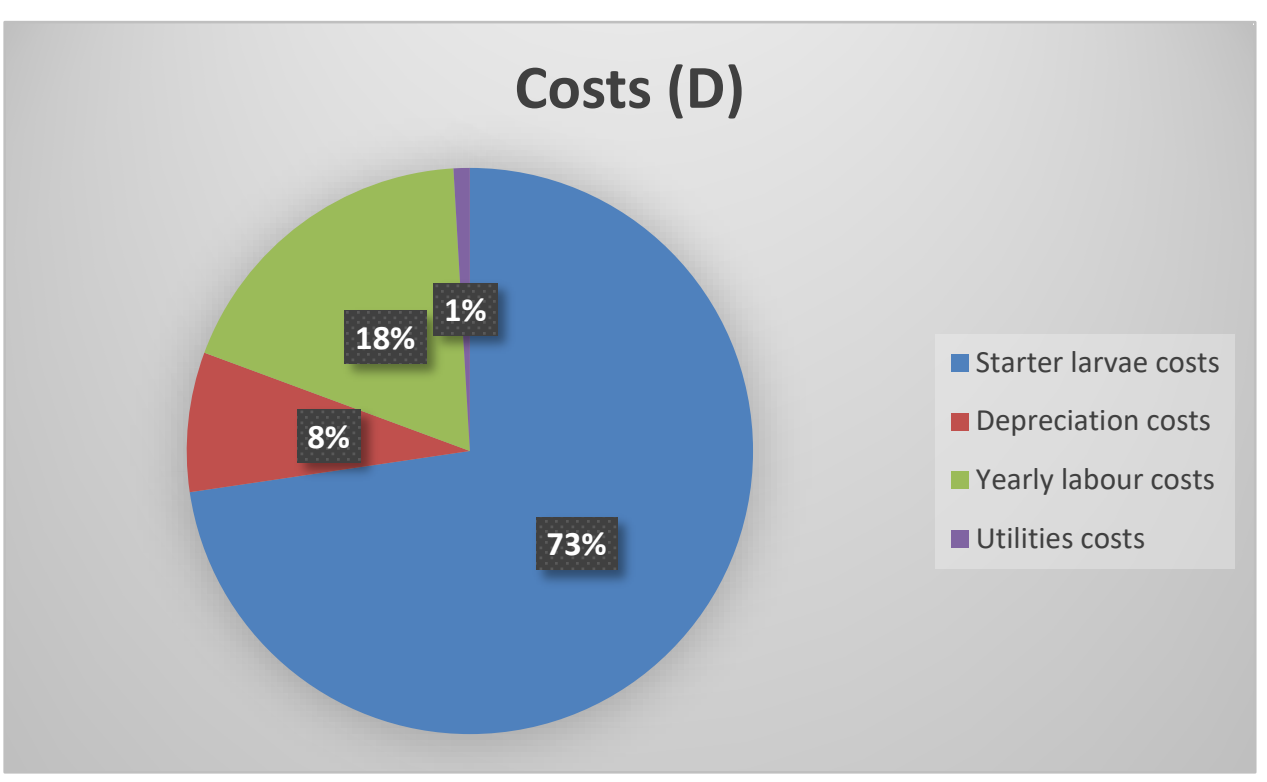

Figure D. 2 Costs for most favourable scenario $D$ 
Table 37 Other key figures for most favourable scenario $D$

\begin{tabular}{|c|c|}
\hline \multicolumn{2}{|l|}{ Other key figures (D) } \\
\hline Amount of dry matter pig manure processed & $270,702 \mathrm{~kg} /$ year \\
\hline Number of insect containers (Rounded up) & 3 containers \\
\hline Number of insect containers (Not Rouded up) & 2.25 containers \\
\hline Starter larvae required & $12,741 \mathrm{~kg} /$ year \\
\hline Yearly BSF dry matter frass produced $\left(Q_{F}\right)$ & $170,542 \mathrm{~kg} /$ year \\
\hline Yearly fresh BSF larvae produced (total) $\left(Q_{T}\right)$ & $104,608 \mathrm{~kg} /$ year \\
\hline Yearly fresh BSF larvae produced (for sale) ( $Q_{B S F L}$ ) & - kg/year \\
\hline Yearly dried BSF larvae produced ( $\left.Q_{B S F}\right)$ & $26,152 \mathrm{~kg} /$ year \\
\hline Electricity used to heat the containers $(E)$ & $30,000 \mathrm{kwh} / \mathrm{year}$ \\
\hline Water used (W) & $265 \mathrm{~m} 3 /$ year \\
\hline
\end{tabular}

\section{Least favourable scenario (E)}

Table 38 Yearly revenues split out for least favourable scenario $E$

\begin{tabular}{llc} 
Revenues split out (E) & $€$ & 86,958 \\
\hline Revenue dried BSF larvae biomass & $€$ & 1,993 \\
\hline Revenue BSF frass & $€$ & 16,242 \\
\hline Reduction in disposal costs & $€$ & - \\
\hline Revenue live BSF larvae biomass & $€$ & \\
\hline
\end{tabular}

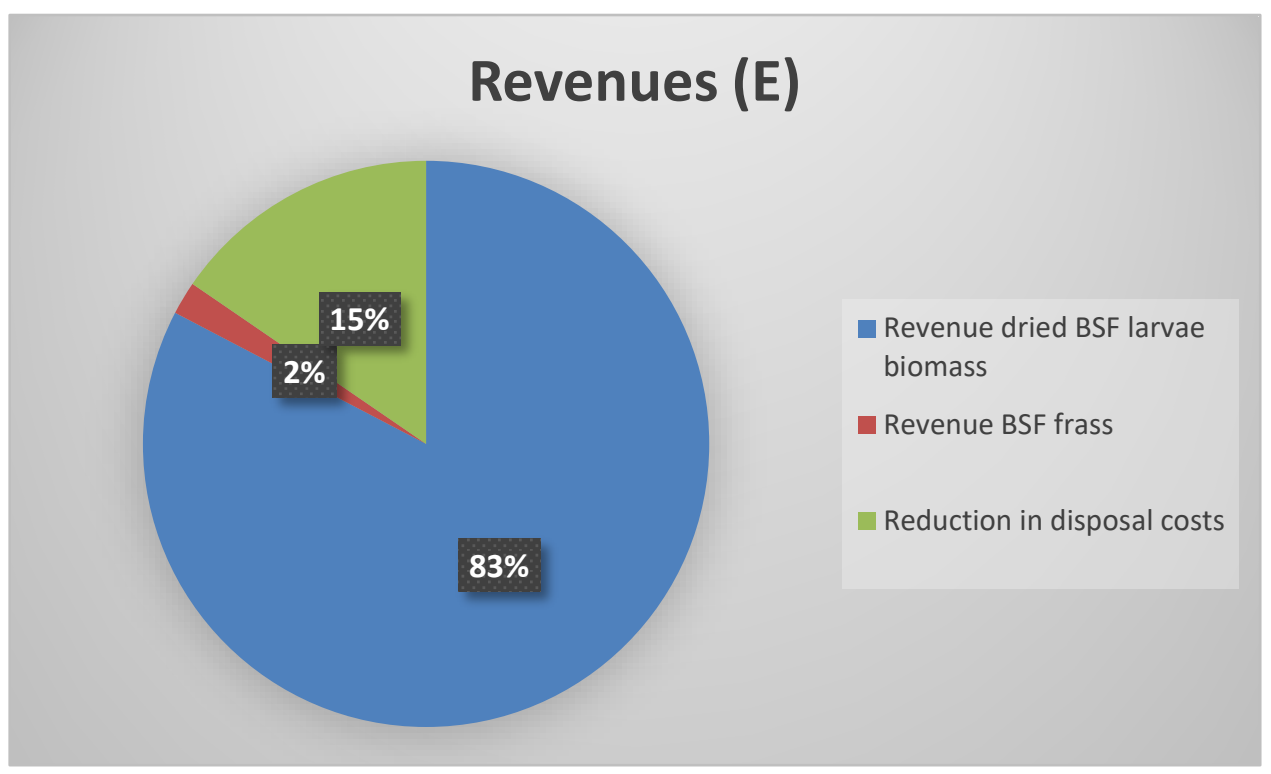

Figure E.1 Revenues for least favourable scenario $E$ 
Table 39 Yearly costs split out for least favourable scenario $E$

\begin{tabular}{llc} 
Costs split out (E) & $€$ & 254,821 \\
\hline Starter larvae costs & $€$ & 38,644 \\
\hline Depreciation costs & $€$ & 92,310 \\
\hline Yearly labour costs & $€$ & 8,018 \\
\hline Utilities costs & $€$ \\
\hline
\end{tabular}

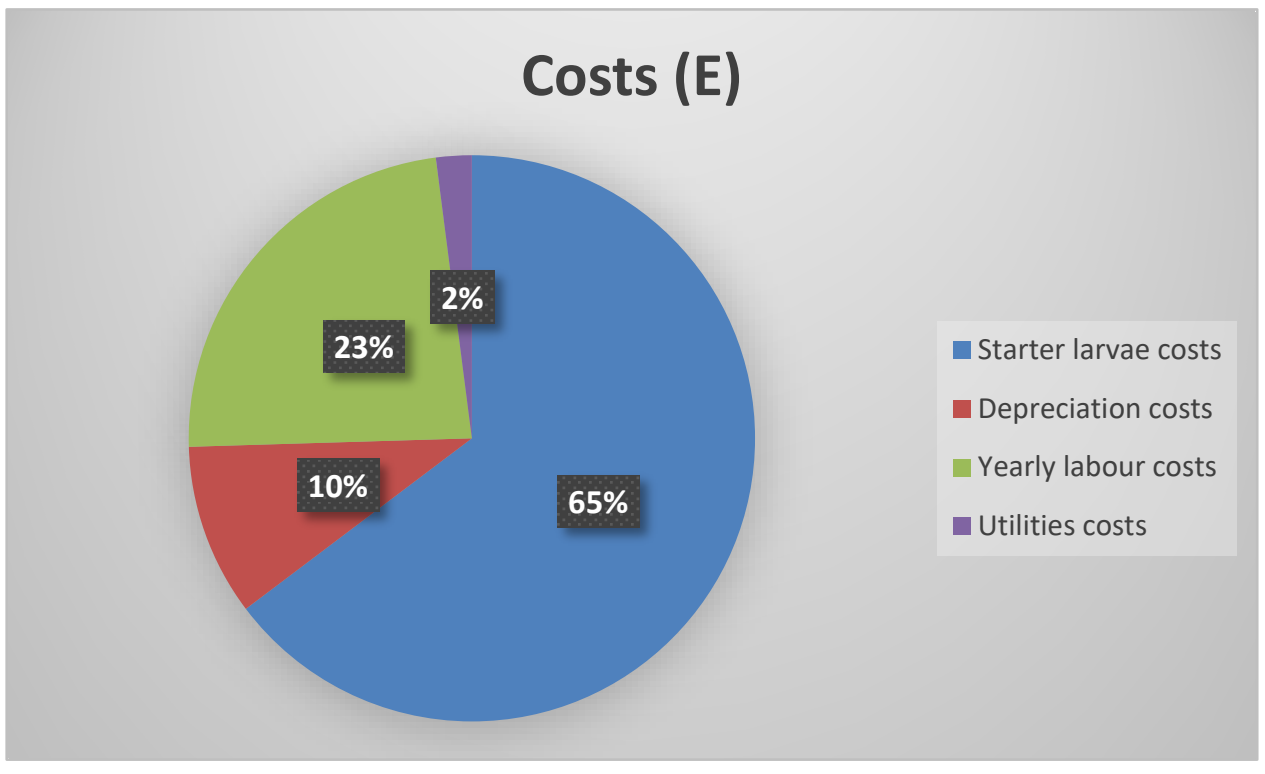

Figure E. 2 Costs for least favourable scenario $E$

Table 40 Other key figures for least favourable scenario $E$

\begin{tabular}{|c|c|}
\hline \multicolumn{2}{|l|}{ Other key figures (E) } \\
\hline Amount of dry matter pig manure processed & $270,702 \mathrm{~kg} /$ year \\
\hline Number of insect containers (Rounded up) & 3 containers \\
\hline Number of insect containers (Not Rouded up) & 2.25 containers \\
\hline Starter larvae required & $12,741 \mathrm{~kg} /$ year \\
\hline Yearly BSF dry matter frass produced $\left(Q_{F}\right)$ & $166,094 \mathrm{~kg} /$ year \\
\hline Yearly fresh BSF larvae produced (total) $\left(Q_{T}\right)$ & $89,187 \mathrm{~kg} /$ year \\
\hline Yearly fresh BSF larvae produced (for sale) ( $Q_{B S F L}$ ) & - kg/year \\
\hline Yearly dried BSF larvae produced (QBSF) & $22,297 \mathrm{~kg} /$ year \\
\hline Electricity used to heat the containers $(E)$ & $39,000 \mathrm{kwh} /$ year \\
\hline Water used (W) & $6371 \mathrm{~m} 3 /$ year \\
\hline
\end{tabular}



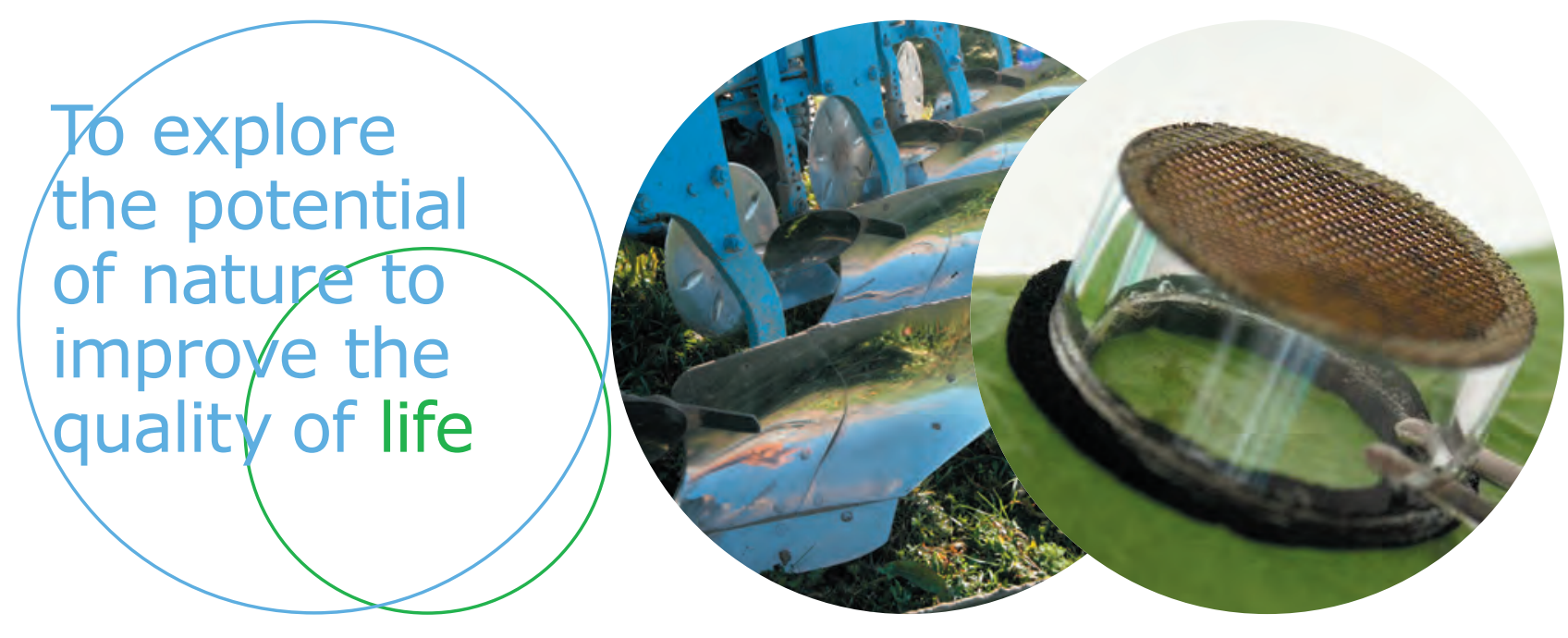

Corresponding address for this report:

P.O. Box 430

8200 AK Lelystad

The Netherlands

T +31 (0)3202911 11

www.wur.eu/plant-research

WPR report -890
The mission of Wageningen University \& Research is "To explore the potential of nature to improve the quality of life". Under the banner Wageningen University \& Research, Wageningen University and the specialised research institutes of the Wageningen Research Foundation have joined forces in contributing to finding solutions to important questions in the domain of healthy food and living environment. With its roughly 30 branches,

6,800 employees (6,000 fte) and 12,900 students, Wageningen University \& Research is one of the leading organisations in its domain. The unique Wageningen approach lies in its integrated approach to issues and the collaboration between different disciplines. 